\title{
The deuterium excess records of EPICA Dome C and Dronning Maud Land ice cores (East Antarctica)
}

\author{
B. Stenni ${ }^{\mathrm{a}, *}$, V. Masson-Delmotte ${ }^{\mathrm{b}}, \mathrm{E}$. Selmo ${ }^{\mathrm{c}}$, H. Oerter $^{\mathrm{d}}, \mathrm{H}_{\text {. Meyer }}{ }^{\mathrm{e}}$, R. Röthlisberger ${ }^{\mathrm{f}}$, J. Jouzel ${ }^{\mathrm{b}}$, \\ O. Cattani ${ }^{\text {b }, ~ S . ~ F a l o u r d ~}{ }^{\text {b }}$, H. Fischer ${ }^{\text {g }}$, G. Hoffmann ${ }^{\text {b }}$, P. Iacumin ${ }^{\text {c }}$, S.J. Johnsen ${ }^{\text {h }}$, B. Minster ${ }^{\text {b }}$, R. Udisti ${ }^{\text {i }}$ \\ ${ }^{a}$ Department of Geological, Environmental and Marine Sciences, University of Trieste, Via E. Weiss 2, 34127 Trieste, Italy \\ ${ }^{\mathrm{b}}$ LSCE /IPSL, UMR CEA CNRS UVSQ 1572, CEA Saclay, L'Orme des Merisiers, 91191 Gif-sur-Yvette, France \\ ${ }^{\mathrm{c}}$ Department of Earth Sciences, University of Parma, Parma, Italy \\ ${ }^{\mathrm{d}}$ Alfred Wegener Institute for Polar and Marine Research, Bremerhaven, Germany \\ e Alfred Wegener Institute for Polar and Marine Research, Potsdam, Germany \\ ${ }^{\mathrm{f}}$ British Antarctic Survey, High Cross, Madingley Road, Cambridge, CB3 OET, UK \\ ${ }^{\mathrm{g}}$ Climate and Environmental Physics, Physics Institute and Oeschger Centre for Climate Change Research, Sidlerstrasse 5, University of Bern, 3012 Bern, Switzerland \\ ${ }^{\mathrm{h}}$ Centre for Ice and Climate, Niels Bohr Institute, University of Copenhagen, Juliane Maries Vej 30, DK-2100, Copenhagen, Denmark \\ ${ }^{\mathrm{i}}$ Department of Chemistry, University of Firenze, Firenze, Italy
}

\section{A R T I C L E I N F O}

\section{Article history:}

Received 30 January 2009

Received in revised form

13 October 2009

Accepted 15 October 2009

\begin{abstract}
A B S T R A C T
New high-resolution deuterium excess $(d)$ data from the two EPICA ice cores drilled in Dronning Maud Land (EDML) and Dome C (EDC) are presented here. The main moisture sources for precipitation at EDC and EDML are located in the Indian Ocean and Atlantic Ocean, respectively. The more southward moisture origin for EDML is reflected in a lower present-day $d$ value, compared to EDC. The EDML and EDC isotopic records $\left(\delta^{18} \mathrm{O}\right.$ and $d$ ) show the main climate features common to the East Antarctic plateau and similar millennial scale climate variability during the last glacial period. However, quite large $\delta^{18} \mathrm{O}$ and $d$ differences are observed during MIS5.5 and the glacial inception with a long-term behaviour. A possibility for this long-term difference could be related to uncertainties in past accumulation rate which are used in the glaciological models. Regional climate anomalies between the two sites during MIS5.5 could also be consistent with the observed EDML-EDC $\delta^{18} \mathrm{O}$ and $d$ gradient anomalies. Simulations performed with the General Circulation Model ECHAM4 for different time slices provide a temporal temperature/isotope slope for the EDML region in fair agreement to the modern spatial slope. $T_{\text {site }}$ and $T_{\text {source }}$ records are extracted from both ice cores, using a modelling approach, after corrections for past $\delta^{18} \mathrm{O}$ seawater and elevation changes. A limited impact of $d$ on Antarctic temperature reconstruction at both EDML and EDC has been found with a higher impact only at glacial inception. The AIM (Antarctic Isotope Maximum) events in both ice cores are visible also after the source correction, suggesting that these are real climate features of the glacial period. The different shape of the AIM events between EDC and EDML, as well as some climate features in the early Holocene, points to a slightly different climate evolution at regional scale. A comparison of our temperature reconstruction profiles with the aerosol fluxes show a strong coupling of the nssCa fluxes with Antarctic temperatures during glacial period and a tighter coupling of $\delta^{18} \mathrm{O}$ and $T_{\text {site }}$ with ssNa flux at EDML compared to EDC during the glacial period and MIS5.5.
\end{abstract}

(c) 2009 Elsevier Ltd. All rights reserved.

\section{Introduction}

Polar ice sheets are among the most powerful natural archives preserving climate information from our "recent" past to the last glacial/interglacial cycles. Deep ice cores, drilled both in Greenland

\footnotetext{
* Corresponding author. Tel.: +39 040558 2153; fax: +39 0405582152.

E-mail address: stenni@univ.trieste.it (B. Stenni).
}

and Antarctica in the last decades, are documenting the natural climate variability experienced by the high latitude regions over the late Pleistocene (NGRIP Members, 2004; EPICA community members, 2004, 2006). This is particularly important when considering the on-going debate on the mechanisms of amplifications of natural and anthropogenic climate variations in polar regions (Masson-Delmotte et al., 2006a,b, 2010; IPCC, 2007). Due to the brevity of direct (instrumental) climate records we must rely on paleoclimate proxies and models, and this is particularly 
true when considering the vast Antarctic ice sheet. Paleotemperature reconstructions from Antarctic ice cores rely mainly on $\delta \mathrm{D}$ and $\delta^{18} \mathrm{O}$ records (Jouzel et al., 2003). The main factors controlling the observed distribution of $\delta \mathrm{D}$ and $\delta^{18} \mathrm{O}$ in Antarctic surface snow are mainly related to the condensation temperature of the precipitation and the origin of moisture (see Masson-Delmotte et al., 2008 for a complete review on the subject).

Application of a simple Rayleigh type model (Ciais and Jouzel, 1994) shows that the $\delta \mathrm{D}$ and $\delta^{18} \mathrm{O}$ of Antarctic snow primarily depend on the temperature of the site, $T_{\text {site, }}$, and to a lesser degree on the average source temperature, $T_{\text {source }}$ (Masson-Delmotte et al., 2004). The reverse holds for the deuterium excess. The deuterium excess, $d=\delta \mathrm{D}-8 \times \delta^{18} \mathrm{O}$ (Dansgaard, 1964), is a second-order isotopic parameter, containing information about conditions prevailing in the source regions of Antarctic precipitation. Through an inversion procedure, $d$ allows the deconvolution of the moisture source temperature and the local temperature at the site of precipitation (Stenni et al., 2001, 2003; Vimeux et al., 2002; Masson-Delmotte et al., 2004). The temperature gradient between the site and the source temperature, which is the driving climate parameter controlling isotopic distillation in the hydrological cycle, can thus be reconstructed with this approach. Since the moisture sources can be spatially variable in time, the aim is not to reconstruct a "local" sea surface temperature profile but to provide information on past changes in moisture transport / precipitation air mass trajectories considering $d$ variations as an integrated tracer of past hydrological cycle changes.

Moreover, the low frequency variability of $d$ appears to be influenced by obliquity fluctuations, which alter the meridional insolation gradient between low and high latitudes and so the latitudinal temperature gradients and the relative contribution of low and high latitudes to polar precipitation (Vimeux et al., 1999; Stenni et al., 2003; Masson-Delmotte et al., 2005).

In the framework of the European Project for Ice Coring in Antarctica (EPICA), two deep ice cores were recovered: one in the Dronning Maud Land Area (EDML), facing the Atlantic Ocean and the other at Dome C (EDC), facing the Indian Ocean. Both of them have already provided a wealth of climate and environmental information respectively spanning the past 140,000 years (e.g. EPICA Community Members, 2006; Fischer et al., 2007) and the past 800,000 years (e.g. Wolff et al., 2006; Jouzel et al., 2007; Lambert et al., 2008; Loulergue et al., 2008; Lüthi et al., 2008). The precipitation and the air mass trajectories of these two sites are influenced by different oceanic basins allowing us to discuss possible different climatic signatures in their respective $d$ records.

As far as Antarctica is concerned, glacial-interglacial $d$ records have already been provided from the old Dome C site (Jouzel et al., 1982), Vostok (Vimeux et al., 1999, 2002), Dome F (Watanabe et al., 2003; Uemura et al., 2004), and for the past 45,000 years also from the EPICA Dome C ice core (Stenni et al., 2001, 2003).

New high-resolution $d$ data obtained from both EPICA ice cores will be presented in this paper. Their isotopic variability $\left(\delta^{18} \mathrm{O}\right.$ and d) will be compared over the past 140,000 years. After corrections for past $\delta^{18} \mathrm{O}$ oceanic water changes and glaciological effects (local elevation changes at both sites and upstream correction at EDML), their combined interpretation in terms of site and source temperature fluctuations will be discussed. We tested this interpretation independently using a general circulation model ECHAM4 fitted with water isotope diagnostics. In particular, we studied the robustness of the temporal temperature/isotope slope for the EDML and Dome $C$ regions running this model under various climate conditions. Finally, the link between the source/site temperature gradient and the sea-salt sodium and non-sea-salt calcium flux records available from both ice cores, will be examined, with a similar approach as in Stenni et al. (2001, 2003).

\section{Materials and methods}

\subsection{Ice core methods}

The EDC ice core drilling site is located at a dome position (see Table 1), $1400 \mathrm{~m}$ west of the topographic dome. At kilometer resolution, the bedrock is relatively flat and the horizontal velocity at the surface is $15 \pm 10 \mathrm{~mm} / \mathrm{yr}$ at the drilling site (Vittuari et al., 2004).

The EDML ice core drilling site (see Table 1 ) is located at Kohnen Station in the interior of the Dronning Maud Land area on a very gentle slope, in the immediate vicinity of an ice divide, which splits approximately $20 \mathrm{~km}$ upstream of the drilling site. The horizontal surface velocity at the drilling site is $0.76 \mathrm{~m} / \mathrm{yr}$ (Wesche et al., 2007). Thus, the ice flow is more complex than at Dome C: instead of a simple vertical thinning, the ice buried below the surface is originating from upstream at higher elevation.

The joint time scales used are EDC3 and EDML1 for the EDC and EDML ice cores respectively. A full description of the EDC3 and EDML1 chronologies is found in Parrenin et al. (2007) and Ruth et al. (2007), respectively, including a detailed discussion of their synchronization error.

Measurements of the two water stable isotopes ( $\delta \mathrm{D}$ and $\delta^{18} \mathrm{O}$ ) were conducted on "bag samples" with a depth resolution of $0.5 \mathrm{~m}$ for EDML and $0.55 \mathrm{~m}$ for EDC. The EDML $\delta^{18} \mathrm{O}$ and $\delta \mathrm{D}$ measurements were conducted in Germany at the Alfred Wegener Institute (AWI), Potsdam, using the $\mathrm{CO}_{2}\left(\mathrm{H}_{2}\right)$ /water equilibration technique (Meyer et al., 2000). The EDC $\delta$ D measurements were conducted in France at Laboratoire des Sciences du Climat et l'Environnement (LSCE) using an automatic injection device and the uranium reduction technique while the EDC $\delta^{18} \mathrm{O}$ measurements were performed in Italy at the Department of Earth Sciences of University of Parma (DST) and at the Department of Geological, Environmental and Marine Sciences of University of Trieste (DiSGAM) using the same technique used at AWI. Intercomparisons of reference waters among the involved laboratories were conducted over the analysis period and the same water standard was used in both LSCE and DST/DiSGAM laboratories. The precision of $\delta^{18} \mathrm{O}$ and $\delta \mathrm{D}$

Table 1

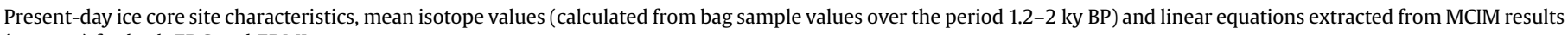
(see text) for both EDC and EDML.

\begin{tabular}{|c|c|c|c|c|c|c|c|c|c|c|}
\hline \multirow[t]{2}{*}{$\begin{array}{l}\text { Ice core } \\
\text { sites }\end{array}$} & Coordinates & $\begin{array}{l}\text { Elevation } \\
\text { WGS84 }\end{array}$ & $\begin{array}{l}\text { Ice } \\
\text { thickness }\end{array}$ & $\begin{array}{l}\text { Mean } \\
\text { S annual } T\end{array}$ & $\begin{array}{l}\text { Acc. } \\
\text { rate }\end{array}$ & $\delta^{18} \mathrm{O}$ & $\delta D$ & $d$ & $\begin{array}{l}\text { Moisture } \\
\text { source } T\end{array}$ & $\Delta T_{\text {source }}$ equation \\
\hline & Lat., Long. & $(\mathrm{m})$ & $(\mathrm{m})$ & $\left({ }^{\circ} \mathrm{C}\right)$ & $\begin{array}{l}\left(\mathrm{kg} \mathrm{m}^{-2}\right. \\
\left.\mathrm{yr}^{-1}\right)\end{array}$ & V-SMOW & V-SMOW & V-SMOW & $\left({ }^{\circ} \mathrm{C}\right)$ & \\
\hline EDC & $\begin{array}{l}75^{\circ} 06^{\prime} 07^{\prime \prime} \mathrm{S} \\
123^{\circ} 23^{\prime} 43^{\prime \prime} \mathrm{E}\end{array}$ & 3233 & $3273 \pm 5$ & -54.5 & 25 & $-50.7 \pm 0.5 \%$ & $-396.3 \pm 4.4 \%$ & $9.3 \pm 0.8 \%$ & $10-15$ & $0.16 \Delta \delta \mathrm{D}_{\text {corr }}+0.44 \Delta d_{\text {corr }} 0.06 \Delta \delta \mathrm{D}_{\text {corr }}+0.93 \Delta d_{\text {corr }}$ \\
\hline EDML & $\begin{array}{l}75^{\circ} 00^{\prime} 09^{\prime \prime} \mathrm{S} \\
0^{\circ} 04^{\prime} 06^{\prime \prime} \mathrm{E}\end{array}$ & 2892 & $2780 \pm 5$ & -44.6 & 64 & $-44.8 \pm 0.8 \%$ & $-353.9 \pm 6.9 \%$ & $4.7 \pm 1.1 \%$ & $5-10$ & $0.13 \Delta \delta \mathrm{D}_{\text {corr }}+0.57 \Delta d_{\text {corr }} 0.04 \Delta \delta \mathrm{D}_{\text {corr }}+1.12 \Delta d_{\text {corr }}$ \\
\hline
\end{tabular}


measurements of both EDC and EDML ice cores is $\pm 0.05 \%$ and $\pm 0.5 \%$ respectively, with a final precision of $0.64 \%$ on $d$.

The precipitation of the past $140 \mathrm{ky} \mathrm{BP}$ (ky BP refers to thousands of years before $1950 \mathrm{AD}$ ) is archived in the upper $2400 \mathrm{~m}$ and $1790 \mathrm{~m}$ of the EDML and EDC ice cores, respectively. High-resolution $\delta^{18} \mathrm{O}$ and $\delta \mathrm{D}$ profiles have already been published for EDML (EPICA Community Members, 2006) and EDC (Jouzel et al., 2007), respectively. The average temporal resolution of the EDML bag data is $\sim 10$ years for the Holocene, $\sim 25$ years for MIS2 (Marine Isotopic Stage 2), $\sim 80$ years for MIS5.5. There are three small gaps in the EDML isotopic profiles: (i) from 681 to $690.5 \mathrm{~m}$ (only $\delta^{18} \mathrm{O}$; $11.57-$ $11.76 \mathrm{ky} \mathrm{BP}$ ), (ii) from 1418 to $1437.5 \mathrm{~m}$ (43.67-44.87 ky BP), (iii) from 2304 to $2309.5 \mathrm{~m}$ (119.01-119.53 ky BP). The average temporal resolution of the EDC bag data is $\sim 18$ years for the Holocene, $\sim 50$ years for MIS2 and $\sim 42$ years for MIS5.5.

As a result of the accumulation difference between the two sites, EDML offers higher resolution than EDC until $\sim 80 \mathrm{ky} \mathrm{BP.} \mathrm{For}$ deeper depths, thinning effects become dominant near bedrock for this site, resulting in a decreased temporal resolution for bag samples compared to EDC.

\subsection{Model methods}

ECHAM4 is an atmospheric general circulation model equipped with a water isotope module allowing the explicit computation of all isotopic fractionation steps in the hydrological cycle. The model physics are detailed in Roeckner et al. (1996). The parameterization of the water isotope physics and the climatology of the water isotopes under modern conditions are described in Hoffmann et al. (1998), and some aspects of the modelled interannual relationships in polar latitudes between the stable water isotopes and climate are discussed in Werner and Heimann (2002). In this study the model is run in T42 resolution referring to the spectral truncation scheme. On the Euclidean grid this corresponds to $\sim 2.8^{\circ} \times 2.8^{\circ}$ resolution. The time step for dynamics and physical sub-grid scale processes is $24 \mathrm{~min}$.

The model has been run for the Last Glacial Maximum (LGM) PMIP1 (Paleoclimate Modelling Intercomparison Project, Phase 1, see http://pmip.lsce.ipsl.fr/) boundary conditions (Hoffmann et al., 2000; Werner et al., 2001). Here, we analyse a set of simulations conducted for boundary conditions of various other time slices (present-day, pre-industrial, 6, 11, 14, 16, LGM and $175 \mathrm{ky} \mathrm{BP).}$ Changes in ice sheet extent (Peltier, 1994), atmospheric greenhouse gas concentration, sea surface temperature (SST) and sea-ice coverage are prescribed. In the 1980s the LGM-today SST amplitude was estimated by the CLIMAP group on a spatial global grid. Here we assume basically that the ocean surface temperatures evolved in a simple near linear way between full glacial conditions and modern climate conditions. Over the last 20,000 years climate warmed up differently in various parts of the globe. We have chosen the temperature evolution deduced from the Greenland GRIP isotope record as representative for high northern latitudes, the global sea level as representative for low-latitude temperatures and the Vostok isotope record as representative for high southern latitudes. These three records were normalized and converted into each other by latitudinal smoothing. The normalized fields then were multiplied with the CLIMAP LGM-today temperature amplitude. Though we tried in this way to take into account some spatial differences in the climate evolution of the last 20,000 years, this approach remains of course a major simplification. The time slice simulations therefore rather should be considered as sensitivity studies under cold climate conditions than state-of-the-art climate reconstructions for the specific periods. Relevant orbital parameters are modified for each time slice. For more details see Table 2 . These simulations have previously been used to support temperature estimates from EPICA Dome C ice core (Jouzel et al., 2007). As also discussed by Masson-Delmotte et al. (2008), ECHAM4 captures the right range of annual mean surface temperature in Antarctica but systematically underestimates present-day isotopic depletion and overestimates modern $d$ values in central Antarctica.

The Mixed Cloud Isotopic Model (MCIM) has been developed by Ciais and Jouzel (1994) to simulate Antarctic isotopic processes and applied to take into account $d$ fluctuations on Antarctic temperature reconstructions. This distillation model includes parameterizations for key aspects of cloud physics in the line of cloud isotopic models developed by Fisher (1990) and Johnsen et al. (1989), and more recently by Kavanaugh and Cuffey (2003). During evaporation at the ocean surface, the diffusion coefficients for the different molecules had been determined by Merlivat and Jouzel (1979), leading to relative imprint of diffusion transport on $\delta \mathrm{D}$ and $\delta^{18} \mathrm{O}$. Temperature thresholds determine the onset of ice crystals formation, and the final freezing of supercooled liquid are fixed, with Bergeron-Findeisen process affecting the clouds being a mixture of liquid and solid water between these thresholds. As previously demonstrated by Ciais and Jouzel (1994), the parameterization of this mixed zone (temperature thresholds, proportion of ice crystal relative to liquid droplets) will not affect strongly the isotopic composition of the falling snow and its relation to temperature. Indeed, the snow isotopic composition is mostly controlled by the relative values of the solid-vapour equilibrium and kinetic fractionation coefficients at the temperature of condensation. While the equilibrium coefficients are well known from experiments and spectroscopic data, the expression of the kinetic fractionation associated to the ice crystal growth is more uncertain. It combines the relative value of diffusion coefficient of the different water molecules in the air and the value of supersaturation over ice during crystal growth. Supersaturation is usually parameterized with a linear relationship to temperature. This function was tuned to represent correctly spatial $d$ fluctuations in Antarctica (Masson-Delmotte et al., 2004). Sensitivity tests run with different parameterizations and tunings for the MCIM show very similar results concerning the relative influences of $T_{\text {source }}$ and $T_{\text {site }}$ on $\delta^{18} \mathrm{O}$ and $d$, strengthening the validity of the proposed temperature inversion. The isotopic simulations are also

Table 2

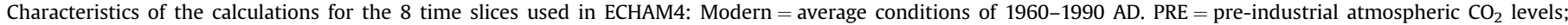
$6 \mathrm{k}=6000$ years BP; $11 \mathrm{k}=11,000$ years BP; $14 \mathrm{k}=14,000$ years BP; $16 \mathrm{k}=16,000$ years BP; $\mathrm{LGM}=21,000$ years $\mathrm{BP} ; 175 \mathrm{k}=175,000$ years $\mathrm{BP}$.

\begin{tabular}{|c|c|c|c|c|c|}
\hline Time slice & $\mathrm{CO}_{2}$ concentration $(\mathrm{ppm})$ & Insolation & Sea surface temperatures & Sea level $(\mathrm{m})$ & $\delta^{18} \mathrm{O}_{\text {sw }}$ \\
\hline Modern & 353 & Modern & Modern & Modern & $0 \%$ \\
\hline PRE & 280 & Modern & Modern & Modern & $0 \%$ \\
\hline $6 \mathrm{k}$ & 280 & 6 ky BP & Modern & Modern & $0 \%$ \\
\hline $11 \mathrm{k}$ & 280 & 11 ky BP & Interpolated & -30 & $0.4 \%$ \\
\hline $14 \mathrm{k}$ & 240 & 14 ky BP & Interpolated & -60 & $0.8 \%$ \\
\hline $16 \mathrm{k}$ & 220 & 16 ky BP & Interpolated & -87 & $1.2 \%$ \\
\hline LGM & 200 & 21 ky BP & CLIMAP & -106 & $1.5 \%$ \\
\hline $175 k$ & 200 & 175 ky BP & CLIMAP & -106 & $1.5 \%$ \\
\hline
\end{tabular}


particularly sensitive to the prescribed proportion of condensates, which precipitate out of the clouds (controlling the closed versus open cloud distillation, and therefore related to the relative weight of clear-sky snowfall with respect to the local cyclonic activity). We have kept the same cloud microphysics parameterizations for EDML and EDC, despite the fact that they have different contributions of clear-sky versus convection precipitation. Another assumption concerns the vertical temperature profile, linking surface to condensation temperatures. We use here the same rough assumption for EDML and EDC, i.e., a linear dependency of condensation temperature to surface temperature ( $T_{\text {cond }}=$ $0.67 T_{\text {surf }}-1.2$; Jouzel and Merlivat, 1984). We are aware that the vertical atmospheric structure is affected by moisture advection during snowfall events (Helsen et al., 2006). We have performed simulations forced with the observed annual mean latitudinal distribution of sea surface conditions (temperatures, relative humidity, wind speed) to evaluate the isotopic dependency on different source conditions. The model tuning used here is consistent with modern moisture source temperatures of $10-15^{\circ} \mathrm{C}$ at EDC and $5-10^{\circ} \mathrm{C}$ at EDML. The limitations of the MCIM model are also discussed in Masson-Delmotte et al. (2008), where the same version of the MCIM model captured reasonably well the spatial distribution of isotope-surface temperature and $d$ profiles in modern Antarctic snow.

\section{Data}

The isotopic measurements are first compared in terms of local meteoric water lines (Fig. 1). The quality of the measurements results in high correlations between $\delta^{18} \mathrm{O}$ and $\delta \mathrm{D}$. The slopes are quite similar for the two sites, on average slightly larger than 8 . When calculated over periods of $5 \mathrm{ky}$, the $\delta \mathrm{D}-\delta^{18} \mathrm{O}$ slope varies between 6.5 and 9 at EDC and 6.3 and 8.7 at EDML. The different intercepts of the EDML and EDC ice core data point to different moisture origins for the two sites, also reflected by their mean $\delta^{18} \mathrm{O}$ and $d$ values (see Table 1 ). The lower intercept of the $\delta \mathrm{D}-\delta^{18} \mathrm{O}$ regression line at EDML, compared to EDC, and the lower presentday $d$ value, are reflecting a more local and colder moisture source for EDML, as expected from backward-trajectory analyses and isotopic modelling. For Dome $\mathrm{C}$ the main moisture sources of precipitation are located at mid-latitudes of the Indian Ocean (Delaygue et al., 2000), with a mean SST of about $10-15^{\circ} \mathrm{C}$, while a more southward moisture origin for EDML is expected. Several authors (Reijmer and van den Broeke, 2001; Reijmer et al., 2002; Helsen et al., 2006; Schlosser et al., 2008b), using different model approaches, suggested that the main moisture source region for precipitation in Dronning Maud Land is the South Atlantic Ocean between latitudes that, depending on the results, range from $40^{\circ}$ and $60^{\circ} \mathrm{S}$. Helsen et al. (2006) also showed a large influence of advection height on the final values of $d$ in precipitation, with the higher $d$ values at higher atmospheric levels reflecting a more distant moisture source and the lower near surface $d$ values attributed to evaporation at higher latitudes, as also suggested by Masson-Delmotte et al. (2008) in their review of Antarctic surface snow isotopic composition. Noone (2008) has also shown that the isotopic composition of Antarctic snow is strongly linked to the strength of midlatitude circulation with different moisture advection paths between coastal and inland areas.

The EDML and EDC $\delta^{18} \mathrm{O}$ records (Fig. 2) share the main features well known for central East Antarctica over the last climatic cycle also observed at Vostok (Petit et al., 1999) and Dome Fuji (Watanabe et al., 2003). They show a similar $\delta^{18}$ O LGM-Holocene magnitude of about $5.3 \%$ as well as a similar millennial scale climate variability during the last glacial period as already pointed out by EPICA Community Members (2006). In principle, long-term differences

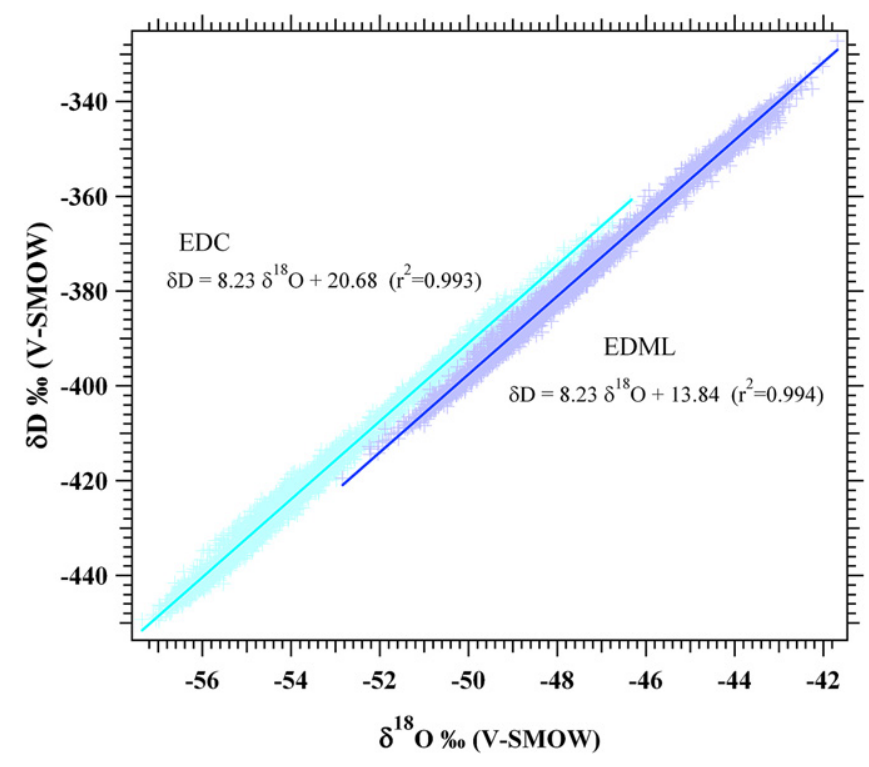

Fig. 1. $\delta^{18} \mathrm{O}-\delta \mathrm{D}$ plot of bag sample data over the past 140,000 years at EDML (average measurements over the same $50-\mathrm{cm}$ samples; dark blue) and EDC (average measurements over the same $55-\mathrm{cm}$ samples; light blue). The regression lines for the two data sets are calculated. In both cases, the quality of the measurements is verified by the high correlations observed between $\delta^{18} \mathrm{O}$ and $\delta \mathrm{D}$.

between the two isotopic profiles could reflect either different climate signals at regional scale and/or local glaciological effects linked with ice origin (important at EDML) and local elevation changes (important at both sites). During the Holocene (see Fig. 7a and $b$ for a zoom on the Holocene) they show: (i) a comparable early optimum, (ii) a $\delta^{18} \mathrm{O}$ minimum at about $8 \mathrm{ky}$ BP more strongly marked at EDC than EDML, and (iii) a mid-Holocene optimum at EDML and more stable values at EDC. During the last deglaciation (Fig. 2) a larger Antarctic Cold Reversal (ACR) peak is shown in the EDC record. During MIS2 rather stable values are observed at EDC (27-18 ky BP) versus a small ( $1 \%$ over $10 \mathrm{ky})$ increasing trend at EDML from 26 ky BP to $17 \mathrm{ky}$ BP, pointing to an "early local LGM". Apart from the AIM (Antarctic Isotope Maximum) 2 event, which is not seen in the EDC record, all the other AIM events are present in both records with more "squared" maxima in the EDML one. During MIS5.5 the two records appear quite different. EDC exhibits a stronger early optimum followed by marked drop afterwards. During the second part of MIS5.5, EDC values appear more stable while EDML data show a slight cooling trend.

The EDML and EDC $d$ records (Fig. 2) show common low frequency variability with relative maxima in correspondence of obliquity minima (or maxima in the insolation gradient between low and high latitudes, at about 30, 70 and $110 \mathrm{ky}$ BP). This obliquity imprint appears with a larger magnitude in the fluctuations at EDC compared to EDML. Both $d$ records show similar LGM-Holocene variation of about 3\%o, only slightly lower at EDML $(2.9 \%$ versus $3.2 \%$ ). The comparison of EDML and EDC $d$ data (Fig. 2) shows: (i) different Holocene trends, with an early optimum in EDC versus an increasing trend for EDML, (ii) opposite trends at the end of MIS5.5-beginning of MIS5.3, when EDC $d$ shows a progressive increase peaking at about $104 \mathrm{ky}$ BP, while EDML $d$ peaks earlier (at 110-114 ky BP), (iii) a decreasing trend at EDML for the oldest period (from 140 to $135 \mathrm{ky} \mathrm{BP}$ ) not seen in EDC. Again, the two records show the largest differences during MIS5.5. Another two features differentiate the two $d$ records. (i) A marked negative peak at $11.5 \mathrm{ky} \mathrm{BP}$ in the EDML core, not seen in the EDC $d$ record (Fig. 7a and b), but unfortunately interrupted by some missing values 


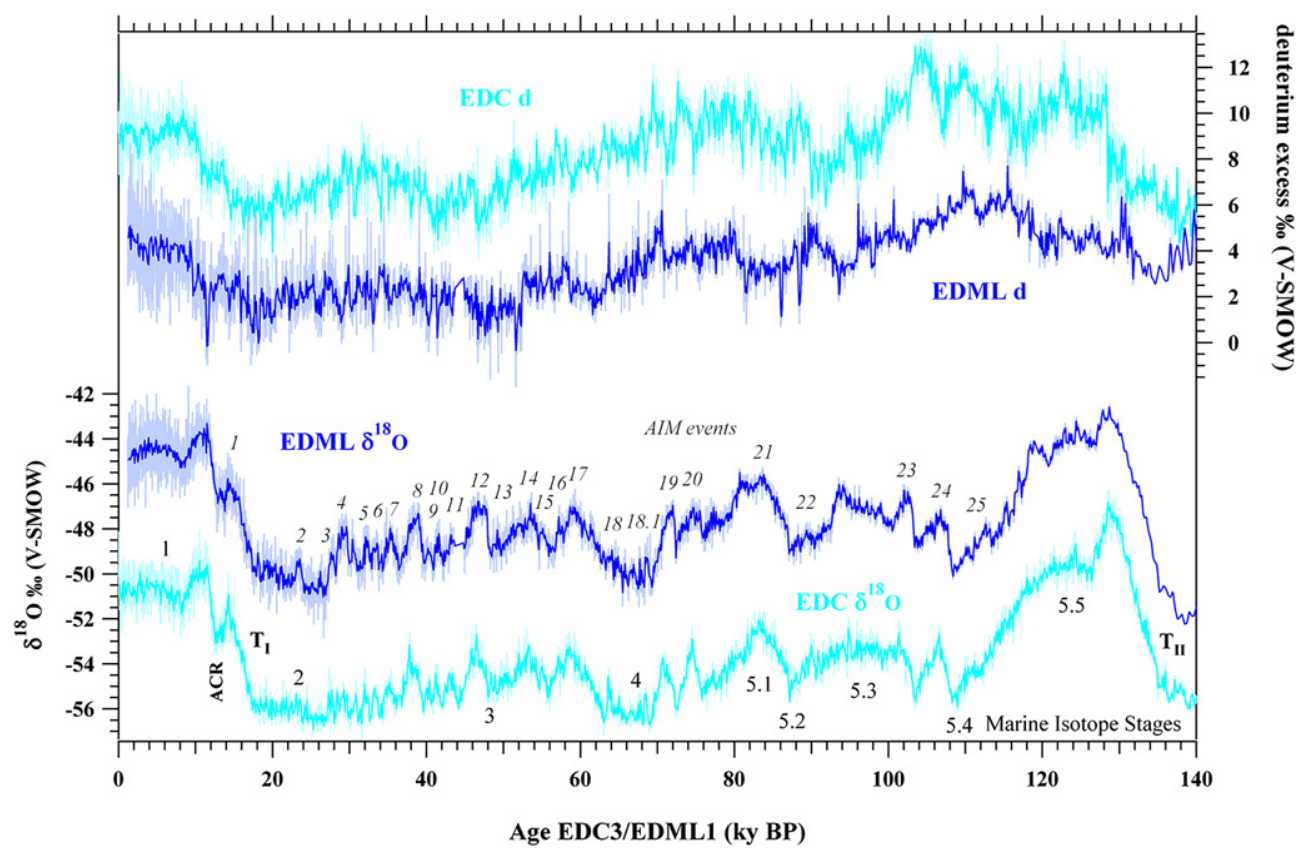

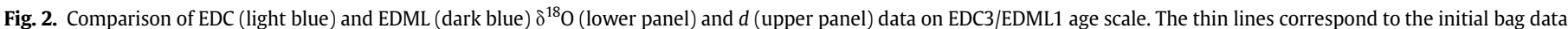

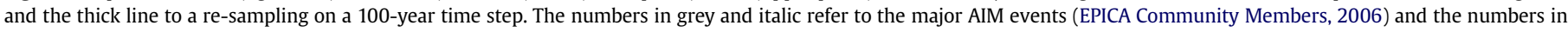
black refer to the Marine Isotope Stage nomenclature.

between 11.57 and $11.76 \mathrm{ky}$ BP. This negative peak is in antiphase with the $\delta^{18} \mathrm{O}$ early Holocene optimum. (ii) Two consecutive fast variations of $d$ in the EDC core at the end of termination II (Fig. 2) (Masson-Delmotte et al., 2010).

\section{Corrections}

Before going further in the quantitative comparison of the differences between $\delta^{18} \mathrm{O}$ and $d$ records obtained from the two EPICA ice cores, some corrections must be applied: one for past changes in the seawater isotopic composition, due to waxing and waning of the continental ice sheets during climatic cycles, and the other for the elevation variations due to both accumulation rate and site deposition elevation changes along the flow line (upstream correction).

\subsection{Correction for seawater isotopic composition}

Uncertainties in the correction for past changes in seawater isotopic composition $\left(\delta^{18} \mathrm{O}_{\mathrm{sw}}\right)$ mostly arise from first the actual moisture source $\delta^{18} \mathrm{O}$ (versus the global signal) and also from the use of a common age scale for $\delta^{18} \mathrm{O}_{\text {sw }}$ and EDC3. Here we consider only changes in $\delta^{18} \mathrm{O}_{\mathrm{sw}}$ resulting from changes in global ice volume and ignore local factors which can alter surface ocean water $\delta^{18} \mathrm{O}$. We also assume that $d$ of the source water is zero. We use the Bintanja et al. (2005) $\delta^{18} \mathrm{O}_{\mathrm{sw}}$ record derived from the marine sediment benthic stacks of Lisiecki and Raymo, 2005 after correction for deep water temperature effects. We apply the following corrections as described in Jouzel et al. (2003):

$$
\begin{aligned}
\delta^{18} \mathrm{O}_{\text {corr }}= & \delta^{18} \mathrm{O}_{\text {ice }}-\delta^{18} \mathrm{O}_{\mathrm{sw}} \times\left(1+\delta^{18} \mathrm{O}_{\text {ice }} / 1000\right) / \\
& \left(1+\delta^{18} \mathrm{O}_{\mathrm{sw}} / 1000\right) \\
\delta D_{\text {corr }}= & \delta D_{\text {ice }}-8 \delta^{18} \mathrm{O}_{\mathrm{sw}} \times\left(1+\delta D_{\text {ice }} / 1000\right) /
\end{aligned}
$$

$$
\left(1+8 \delta^{18} O_{\mathrm{sw}} / 1000\right)
$$

The deuterium correction versus $\delta^{18} \mathrm{O}_{\mathrm{sw}}$ has an averaged slope of 5 , as in Stenni et al. (2001, 2003). This correction increases the glacialinterglacial magnitude by about $10 \%$ for $\delta^{18} \mathrm{O}$ and $\delta \mathrm{D}$ and therefore enhances the magnitude of reconstructed Antarctic temperature change. The correction is slightly larger at EDML compared to EDC. This is due to the attenuation of the initial vapour isotopic signal after a more intense isotopic depletion at Dome $\mathrm{C}$ (Jouzel et al., 2003). The $\delta^{18} \mathrm{O}_{\mathrm{sw}}$ correction has a major effect on $d$, with a magnitude of correction of $3.2 \%$ at EDC and $2.9 \%$ at EDML for LGM, comparable to the magnitude of LGM-present-day $d$ anomalies. As a result, the shape of $d_{\text {corr }}$ is significantly altered (Fig. 3). Because the magnitude of these corrections is dependent on the degree of distillation and therefore different for EDML and EDC, we now compare the seawater corrected isotopic profiles (Fig. 3). The EDC and EDML $\delta^{18} \mathrm{O}_{\text {corr }}$ and $d_{\text {corr }}$ anomalies (with respect to their mean value during the time period from 1.2 to $2 \mathrm{ky} \mathrm{BP}$ ) are reported in Fig. 3. The gradients between EDML and EDC $\delta^{18} \mathrm{O}_{\text {corr }}$ and $d_{\text {corr }}$ anomalies are also displayed in Fig. 3, along with their long-term components (red lines) calculated using the four principal components of a Singular Spectrum Analysis. When looking at the $\delta^{18} \mathrm{O}_{\text {corr }}$ difference between the two sites, EDML isotopic anomalies are $\sim 0.5-1.5 \%$ weaker than at EDC from 28 to $85 \mathrm{ky} \mathrm{BP}$ and from 93 to $104 \mathrm{ky}$ BP. On the contrary, EDML isotopic anomalies are systematically below EDC from 110 to 140 ky BP.

The differences in $\delta^{18} \mathrm{O}_{\text {corr }}$ between EDML and EDC may arise from different processes: (i) different temperature histories at EDML and EDC, (ii) different distributions of precipitation through the year at EDML and EDC, (iii) different isotopic distillation (moisture origin, trajectories) at EDML and EDC, (iv) local biases due to changes in ice sheet elevation at EDML and EDC, (v) local EDML bias due to the upstream origin of the deepest ice, and (vi) uncertainties in the synchronization of the age scales. 


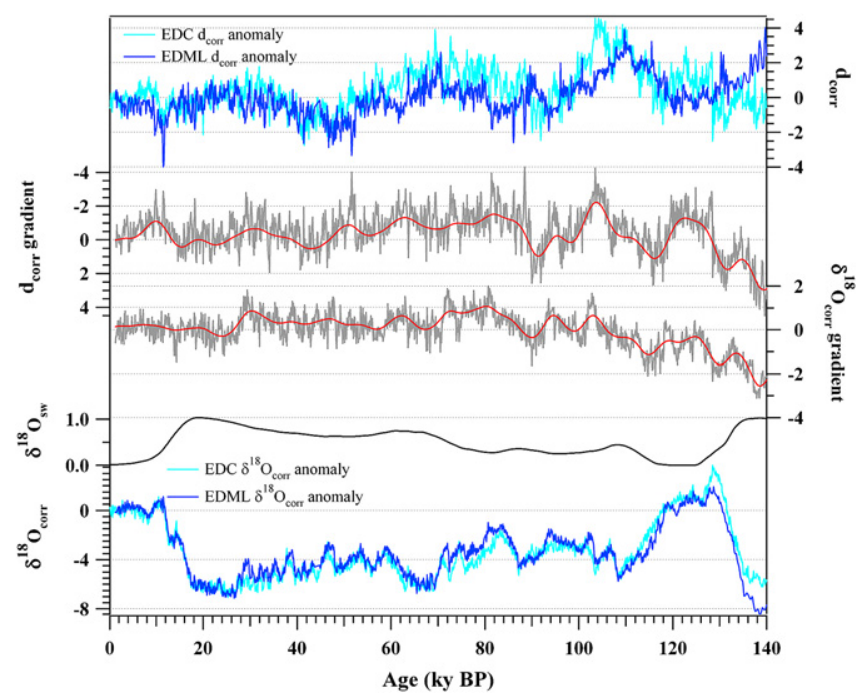

Fig. 3. Comparison of EDC (light blue) and EDML (dark blue) $\delta^{18} \mathrm{O}_{\text {corr }}$ anomalies (with respect to their mean value over the time period from 1.2 to $2 \mathrm{ky} \mathrm{BP}$ ) on a 100 -year time step after correction for seawater isotopic composition, reported on the EDC3/ EDML1 age scale. The $\delta^{18} \mathrm{O}_{\text {sw }}$ record (Bintanja et al., 2005), displayed as a black line, is derived from the marine sediment benthic stacks of Lisiecki and Raymo, 2005 after correction for deep water temperature effects. The gradients between EDML and EDC $\delta^{18} \mathrm{O}_{\text {corr }}$ and $d_{\text {corr }}$ (reversed scale for coherency with $\delta^{18} \mathrm{O}_{\text {corr }}$ ) are displayed as grey lines. Their long-term components (periodicities below $5 \mathrm{ky}$ ) are calculated using the first four components of a Singular Spectrum Analysis (red lines).

\subsection{Correction for glaciological effects: upstream origin,} local elevation changes

In previous papers (EPICA Community Members, 2006; Jouzel et al., 2007) a correction for glaciological factors was applied for each site. For EDML, Huybrechts et al. (2007) run a glaciological model forced by a first guess of EDC and EDML temperature and accumulation profiles derived from the ice core data. They calculated both the local elevation history and the upstream origin of EDML ice, both expressed in elevation (m) (Fig. 4). This total glaciological correction was then used to correct EDML $\delta^{18} \mathrm{O}$ using the present-day local isotope-elevation slope $(-0.96 \%$ per $100 \mathrm{~m})$. The magnitude of this correction reaches several $\%$. The $\delta^{18} \mathrm{O}-$ elevation relationship in the EDML area, based on all snow pit and firn core data collected upstream and around the EDML drilling site, ranges between -0.63 and $-0.95 \%$ per $100 \mathrm{~m}$, with a mean regional slope of $-0.76 \%$ per $100 \mathrm{~m}$. Since, we have no means to look at the temporal changes of the vertical isotopic lapse rate, we used the same value for the whole profile.

For EDC, Parrenin et al. (2007) ran a 1D ice flow model in an inversed glaciological method. In addition to the dating of the ice core, this method also produces a reconstruction of local ice thickness (mainly responding to accumulation changes). This estimate of past elevation change was used to correct isotope-derived temperature variations at EDC in order to provide a temperature history "at fixed elevation" (Jouzel et al., 2007) using a slope of $-0.9^{\circ} \mathrm{C}$ per $100 \mathrm{~m}$. For EDC, it is possible to compare the results of the Parrenin and Huybrechts models (Fig. 4): despite similar longterm fluctuations, the two modelling approaches give different values from late MIS5.5 to MIS4. It is therefore expected that glaciological factors should induce several \% differences in longterm fluctuations of $\delta^{18} \mathrm{O}$ between EDML and EDC ice core data (Fig. 4). Surprisingly, the actual $\delta^{18} \mathrm{O}_{\text {corr }}$ gradient between EDML and EDC strongly differ from the modelled elevation difference. In particular, the $\delta^{18} \mathrm{O}_{\text {corr }}$ gradient (reported in Fig. 4 on a reversed axis) shows a $\sim 1 \%$ anomaly from about 30 to $80 \mathrm{ky}$ BP of opposite

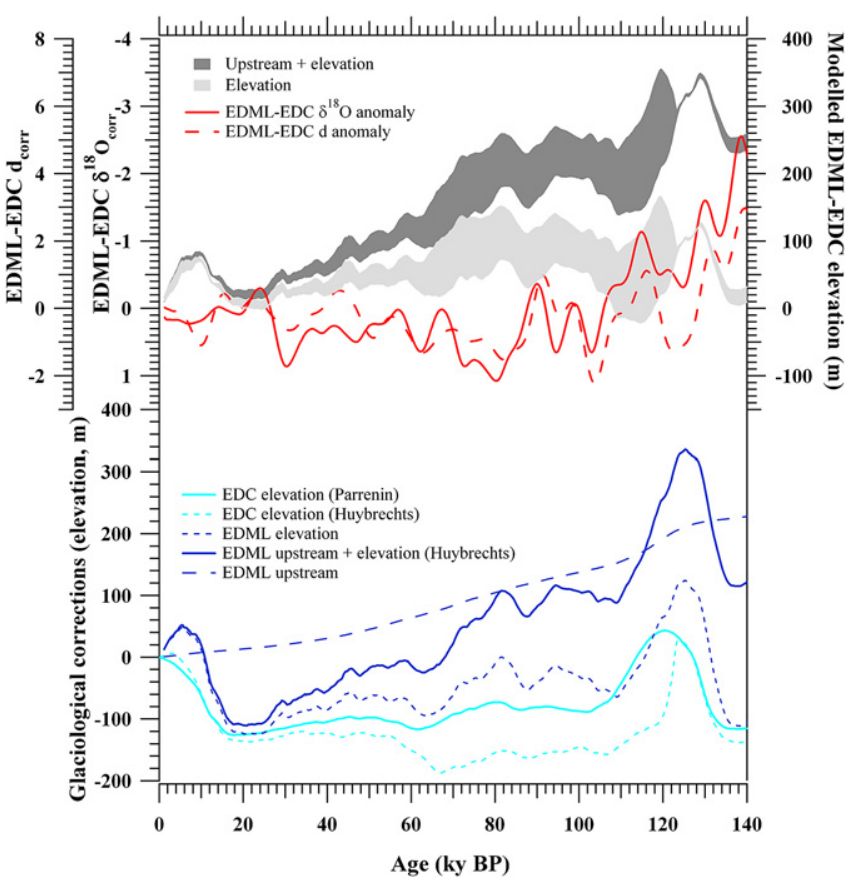

Fig. 4. Bottom panel: Comparison between simulated glaciological effects for EDML (dark blue) calculated as the sum (thick solid line) of elevation changes due to upstream (long dashed line) and local elevation changes (dashed line) (Huybrechts et al., 2007) and EDC (light blue) local elevation changes calculated by Parrenin et al. (2007) (thick solid line) and Huybrechts et al. (2007) (dashed line). Top panel: Comparison between glaciological induced elevation difference between EDML and EDC taking into account local elevation effects (light grey, uncertainty due to the two different model results for EDC) and taking into account both upstream and local elevation effects (dark grey, uncertainty due to the two different model results for EDC) with the long-term fluctuations of the gradients between EDML and EDC $\delta^{18} \mathrm{O}_{\text {corr }}$ (solid red line on a reversed axis) and $d_{\text {corr }}$ (dashed red line) (see Fig. 3). Changes in elevation ( $\mathrm{m}$, right axis) can be directly converted to changes in $\delta^{18} \mathrm{O}(\%$, left axis) using the spatial modern slope ( $\sim 1 \%$ per 100 m elevation).

sign compared to that expected from the modelled elevation gradient. Also after having applied these elevation corrections (not shown), the $\delta^{18} \mathrm{O}_{\text {corr }}$ gradient still shows a positive anomaly from 30 to $80 \mathrm{ky} \mathrm{BP}$ and large long-term fluctuations from about 80 to $140 \mathrm{ky} \mathrm{BP}$. We also tested the different $\delta^{18} \mathrm{O}$ elevation gradients used in the EDML correction but these influence only the amplitude of the final temperature calculation mainly at MIS5.5 but not the long-term trends or the fluctuations observed in the EDML-EDC $\delta^{18} \mathrm{O}_{\text {corr }}$ gradient anomaly profile.

This mismatch is puzzling and raises several questions:

- Can this be a real regional climatic anomaly? Is it possible to have a different temperature magnitude over the long term at EDML versus EDC? Despite the difficulties raised by inconsistencies in age scales, the similarities between EDC and Dome Fuji $\delta^{18} \mathrm{O}$ profiles (Watanabe et al., 2003) seems to act against such a hypothesis.

- Is it possible that glaciological models do not solve correctly the upstream origin of deep EDML ice or the different local elevation histories at both sites? We suggest that one key factor of uncertainty is the accumulation rate estimated using stable isotope data, in agreement with other authors (Landais et al., 2006; Capron et al., 2010; Dreyfus et al., 2010) who are also questioning the accumulation model results. Elevation histories simulated by glaciological models are mostly influenced by the hypothesis on past accumulation changes which could therefore be a possible source of error. 
Past elevation changes are expected to have a signature both in $\delta^{18} \mathrm{O}$ but also in $d$ records. The spatial distribution of $d$ in Antarctic surface snow (Masson-Delmotte et al., 2008) exhibits a relationship with elevation, with a slope of $\sim 0.5 \%$ per $100 \mathrm{~m}$ for sites above $2000 \mathrm{~m}$ elevation (respectively $\sim-1.1 \%$ per $100 \mathrm{~m}$ for $\delta^{18} \mathrm{O}$ and $\sim$ $-8.1 \%$ per $100 \mathrm{~m}$ for $\delta \mathrm{D}$ ). As previously done for $\delta^{18} \mathrm{O}$, the differences in $d$ between EDML and EDC are expected to reflect either different moisture source histories, but they could also be influenced by different local temperature and elevation variations.

The $d_{\text {corr }}$ gradient between EDML and EDC is displayed in Figs. 3 and 4 (plotted in Fig. 3 on a reversed axis). The long-term trend (red line) seems anti-correlated with the long-term $\delta^{18} \mathrm{O}_{\text {corr }}$ gradient with a slope of $\sim 2 \%$ excess per $\% \delta^{18} \mathrm{O}_{\text {corr }}$ This slope is surprising if elevation differences are to be involved, because spatial gradients in central East Antarctica are expected to produce a ratio of $0.5 \%$ $d$ per $\% \delta^{18} \mathrm{O}$ (Masson-Delmotte et al., 2008). In order to keep our corrections coherent with the approach linking elevation and isotopic gradients, we have decided to correct the EDML initial $d$ using the modern spatial gradient of $0.5 \% d$ per $\%$ o $\delta^{18} \mathrm{O}$.

We suggest that a possibility for this long-term difference could be related to uncertainties in past accumulation rate which at the end are used in the glaciological models. However, different temperature/climate history at MIS5.5 between the two oceanic sectors (Atlantic versus Indian ocean), as well as differences in the precipitation regime, and in the air mass trajectories characterized by different $\delta^{18} \mathrm{O}$ and $d$ precipitation values (Schlosser et al., 2008b), could also be consistent with the observed gradients.

\section{ECHAM4 simulations for EDC and EDML areas}

As distillation models do not resolve many processes such as convection, mixing, seasonality, changes in moisture trajectories, they remain limited tools to explore past changes in the relationship between the isotopic composition of precipitation and climate. Since seasonality effects in precipitation may induce biases in the temperature reconstruction performed with stable isotopes, important clues may be obtained from GCM simulations. Information on the seasonal pattern of precipitation for Dome $\mathrm{C}$ and Dronning Maud Land model grid regions was obtained from the ECHAM4 simulations performed for different time slices. For Dome $C$ the model does not show seasonality in the precipitation for present-day, with only slightly higher precipitation during winter, in agreement with Reijmer et al. (2002) on the basis of the ECMWF reanalysis (ERA-15) data set. Moreover, the precipitation seasonality does not change for different climate states. For Dronning Maud Land ECHAM4 simulates higher precipitation in autumn and spring but the pattern is similar also for the other time slices. Reijmer et al. (2002) reported also a peak in modelled precipitation during autumn for the EDML site. However, direct meteorological observations showed an intermittent character of the snow accumulation for this area (Reijmer and van den Broeke, 2001; Helsen et al., 2006) with only few larger events per year, more pronounced in the coastal area than inland where accumulation is more even distributed in the year (Reijmer and van den Broeke, 2003). Accordingly, the ECHAM4 simulation for present-day precipitation seasonality seems quite realistic for the background advection of moisture to EDML.

ECHAM4 simulations allow defining the temporal temperature/ isotope slope for the EDML model grid region (Fig. 5). The obtained value of $0.76 \% /{ }^{\circ} \mathrm{C}$, for the $\delta^{18} \mathrm{O}$-temperature relation, is close (within $7 \%$ ) to the modern spatial analogue of $0.82 \% /{ }^{\circ} \mathrm{C}$ reported by Oerter et al. (1999) and practically equal to the $0.77 \% /{ }^{\circ} \mathrm{C}$ value reported by Graf et al. (2002) for the Dronning Maud Land area.

For the Dome $\mathrm{C}$ model grid region a slope value of $6.2 \% \mathrm{o} /{ }^{\circ} \mathrm{C}$ for the temporal $\delta \mathrm{D}$-temperature relation has been previously

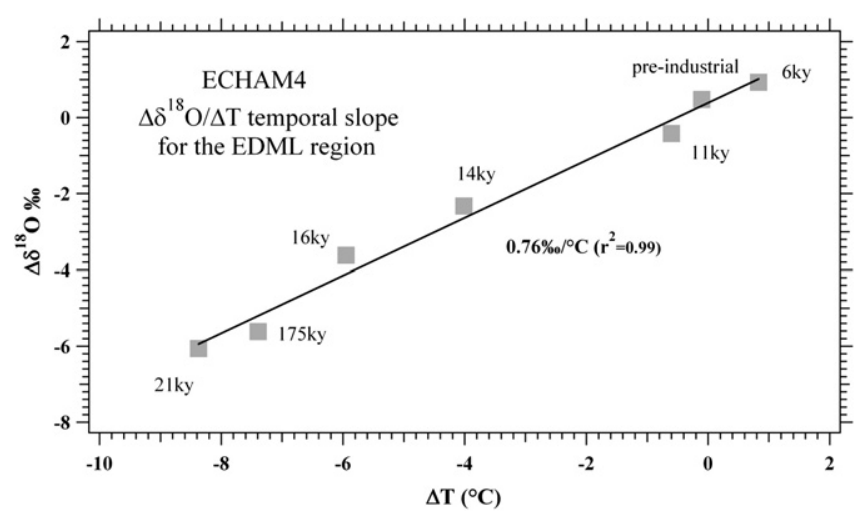

Fig. 5. Temporal $\delta^{18} \mathrm{O} / \mathrm{T}$ relation for the EDML area obtained from new simulations performed with the isotopic version of ECHAM4 General Circulation Model for different time slices.

reported by Jouzel et al. (2007). The $\Delta \delta^{18} \mathrm{O}$ between LGM and preindustrial values are well captured by the model, with a $\Delta \delta^{18} \mathrm{O}_{\text {model }}$ of $6.1 \%$ against a $\Delta \delta^{18} \mathrm{O}_{\text {observed }}$ of $5.3 \%$ for both sites. However, two points should be kept in mind. The near perfect correspondence between the observed spatial isotope/temperature slope on one hand and the temporal isotope/temperature slope on the other hand for the two sites (EDML and Dome C) is not a general feature of the entire Antarctic ice sheet. There is some considerable spatial variability in the simulation of the temporal slope. Even when only analysing East Antarctica we computed temporal slopes varying from rather low values in the Vostok area $\left(5.5 \% /{ }^{\circ} \mathrm{C}\right)$ to high values in the Dome Fuji area $\left(8.5 \% \circ /{ }^{\circ} \mathrm{C}\right)$. The possible reasons for this simulated variability will be analysed in detail in forthcoming studies. In general, the model computes temporal slopes for our time slice computations that are within 30\% in agreement with the modern spatial isotope/temperature gradient.

In summary, effects of seasonality on the isotopic paleothermometer, as they were hypothesized for Greenland (Werner et al., 2000), therefore, seem of minor importance for East Antarctica, based on PMIP1 boundary conditions (Joussaume and Taylor, 1995). Moreover, the similarity of the temporal slope with the spatial slope ( $\pm 30 \%$ ) supports the MCIM based approach used in this study.

\section{6. $T_{\text {site }}$ and $T_{\text {source }}$ reconstruction and uncertainties}

In order to translate isotopic levels into temperature estimates and to account for their interplay, we have decided to perform an isotopic inversion following the method of Stenni et al. (2001, 2003).

Physically, the $\delta^{18} \mathrm{O}$ or $\delta \mathrm{D}$ composition of Antarctic snow should be influenced by the initial vapour isotopic composition (therefore depending on evaporation conditions) and by the distillation range. Conversely, $d$ is imprinted by initial evaporation conditions (Merlivat and Jouzel, 1979; Uemura et al., 2008) but is then influenced by first the equilibrium fractionation associated with air mass cooling (slight dependency on temperature of the fractionation ratio of deuterium and oxygen-18 and therefore on the apparent meteoric water line) and second by kinetic fractionation taking place during ice crystal formation (Jouzel and Merlivat, 1984) and therefore by the relative magnitude of distillation taking place over existing ice phase in the clouds. Due to the lack of constraints, it is not possible with only $\delta^{18} \mathrm{O}$ and $\delta \mathrm{D}$ data to assess the full range of unknown parameters (source temperature, relative humidity, wind speed) influencing initial vapour isotopic composition, together with cloud microphysics and $T_{\text {site }}$ changes. We have therefore considered the evaporation conditions only in terms of source temperature, which is slightly different from the approach of Vimeux et al. (2002), who 
assumed, based on climate models, a relationship between relative humidity and source temperature. Also, it must be noted that the reduction to just site and one source temperatures is a simplistic approach and that in reality air masses can be replenished with a combination of different moisture sources and precipitation events are associated with specific site temperature anomalies (Helsen et al., 2006, 2007). Recently, Schmidt et al. (2007) have shown, by means of coupled ocean-atmospheric model simulations, that $d$ signal of Antarctic precipitation is strongly negatively correlated to the Southern Annular Mode (SAM), and so to the strength of westerly winds.

In practice, the MCIM was run with a variety of source and site conditions in the range of EPICA Dome C present-day and glacial site temperatures (Stenni et al., 2001, 2003; Masson-Delmotte et al., 2004), and multiple linear regressions were performed to extract the linear system. $\Delta$ means anomalies from values averaged over the period 1.2-2 ky BP, $T_{\text {site }}$ is surface temperature and $T_{\text {source }}$ is an average ocean source temperature (equation system 1 ):

$\Delta T_{\text {site }}=0.16 \pm 0.02 \Delta \delta D_{\text {corr }}+0.44 \pm 0.15 \Delta d_{\text {corr }}$

$\Delta T_{\text {source }}=0.06 \pm 0.03 \Delta \delta D_{\text {corr }}+0.93 \pm 0.15 \Delta d_{\text {corr }}$

The equations ( 3 ) and (4) are the same as used in Stenni et al. (2001, 2003).

The uncertainties on the coefficients are calculated from multiple linear regressions from different subsets of simulation runs under different site and source temperature ranges. They are not linked to the MCIM parameterization.

The uncertainty on reconstructed temperatures results from the analytical uncertainty (strongly reduced when averaging $d$ values over a long time period), the uncertainty on the correction for $\delta^{18} \mathrm{O}_{\mathrm{sw}}$, the uncertainty on the linear model and MCIM tuning, from the restriction of evaporation conditions to $T_{\text {source }}$ and from changes in the strength of the inversion layer. Monte Carlo simulations performed with the MCIM had previously shown the robustness of this approach with error estimates lower than $\pm 0.5^{\circ} \mathrm{C}$ (Stenni et al., 2001). Other sources of biases such as deposition and postdeposition effects are ignored. It is thus estimated that the uncertainty on the reconstructed $T_{\text {site }}$ and $T_{\text {source }}$ is within $\pm 2{ }^{\circ} \mathrm{C}$.

For EDC, linear regressions were conducted in the temperature range varying by $\left[-10,+5^{\circ} \mathrm{C}\right]$ around present-day annual mean surface temperature $\left(-54.5^{\circ} \mathrm{C}\right)$. For EDML we have performed linear regressions on the same simulations but with local temperature varying around EDML present-day mean surface temperature $\left(-44.6^{\circ} \mathrm{C}\right)$. As the key factors controlling distillation, such as equilibrium fractionation, or the condensation occurring on ice crystals, differ depending on the temperature range, slightly different linear regression coefficients are obtained for EDML (equation system 2):

$\Delta T_{\text {site }}=0.13 \pm 0.02 \Delta \delta D_{\text {corr }}+0.57 \pm 0.15 \Delta d_{\text {corr }}$

$\Delta T_{\text {source }}=0.04 \pm 0.03 \Delta \delta D_{\text {corr }}+1.12 \pm 0.17 \Delta d_{\text {corr }}$

In order to assess the differences between isotopic profiles (and therefore classical isotopic paleothermometry), isotopic inversion, and elevation corrections, we have displayed on Fig. 6a (EDC) and $\mathrm{b}$ (EDML) the initial isotopic values (grey), $\Delta T_{\text {site }}$ without elevation correction (light pink) and with elevation correction (red) and $\Delta T_{\text {source }}$ with elevation correction (red). Moreover, Fig. 7a and b show a zoom over the Holocene of the EDC and EDML records, respectively.

For EDC (Fig. 6a), the site and source inversion has only limited effects compared to the initial isotopic values. Compared to a classical temperature reconstruction, $\Delta T_{\text {site }}$ mostly differs along MIS5 (and to some extent also during MIS4) with temperatures $\sim 2{ }^{\circ} \mathrm{C}$ higher than a classical inversion, a value which is in the range of temperature reconstruction uncertainties. This results from high $d$ values from 128 to $70 \mathrm{ky} \mathrm{BP.} \mathrm{A} \mathrm{warmer} \mathrm{moisture} \mathrm{source}$ is expected to enhance the isotopic depletion and therefore to induce an overestimation of local temperature changes with the classical paleothermometry method. $\Delta T_{\text {site }}$ shows a sharper optimum at the beginning of MIS5.5, a secondary optimum at $123 \mathrm{ky} \mathrm{BP}$, and two events during the glacial inception. The second event has already been identified as the Antarctic counterpart of DO25 (Jouzel et al., 2007) and appears clearly in $\delta^{18} \mathrm{O}$ (or $\delta \mathrm{D}$ ), $d$ and both $\Delta T_{\text {site }}$ and $\Delta T_{\text {source }}$ (Fig. 8). A similar precursor event is also identified at $115 \mathrm{ky}$ BP suggesting common variability between $T_{\text {site }}$ and $T_{\text {source }}$ of increasing magnitude over the glacial inception.

EDC $d$ and $\Delta T_{\text {source }}$ (Fig. 6a) show a step shape behaviour during termination II with a first sharp increase at about $131 \mathrm{ky} \mathrm{BP}$ followed by a plateau, quite similar to the oceanic cold reversal of termination I (Stenni et al., 2001), and a second step at about $128.5 \mathrm{ky}$ BP reaching levels almost similar to the Holocene $(d)$ or already beyond ( $\left.\Delta T_{\text {source }}\right)$. This second plateau corresponds to the early MIS5.5 Antarctic optimum, well above Holocene values. So the early Antarctic optimum cannot be generated only by changes in moisture origin. At the end of MIS5.5 $d$ and $\Delta T_{\text {source values }}$ increase above present-day levels and the highest value of $d$ (Fig. 6a) is obtained at MIS5.4 (104 ky BP). The isotopic modelling, however, suggests that these glacial inception values are exceptionally high due to the impact of colder Antarctic temperatures during this time. After the isotopic inversion, $\Delta T_{\text {source }}$ peaks earlier than $d$ and show maximum intensity during MIS5.5 (128 ky BP), up to $3{ }^{\circ} \mathrm{C}$ above present-day values. These warmer moisture sources during MIS5.5 are compatible with some paleoclimatic reconstructions available in the Indo-Pacific sector of the Southern Ocean (Barrows et al., 2007; Govin et al., 2009).

The elevation correction has no influence on the final EDC

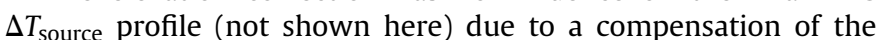
corrections on each isotope with the linear inversion model. For $\operatorname{EDC} \Delta T_{\text {site, }}$, the corrections for changes in moisture source and in local elevation have different consequences of rather similar magnitudes (Fig. 6a). The elevation effects are dominant from 70 ky BP to LGM, increasing the temperature magnitude; the source effects are dominant from MIS6 to $70 \mathrm{ky} \mathrm{BP}$, decreasing the temperature magnitude, and partly compensated by elevation corrections.

For EDML $\Delta T_{\text {site }}$ (Figs. $6 \mathrm{~b}$ and $7 \mathrm{~b}$ ), the correction for moisture sources gives the following results: (i) an attenuation of early interglacial maxima and mid interglacial optima; (ii) a strong reduction of the ACR peak during termination I, forming a plateau of rather constant $\Delta T_{\text {site }}$ values; (iii) a slight decrease in the magnitude of cold events.

The uncertainty on the MCIM tuning may affect the source correction by typically up to $2{ }^{\circ} \mathrm{C}$ for specific time periods (such as LGM or MIS5.5 magnitude) but does not change the shape of EDML $\Delta T_{\text {site. }}$. The upstream/elevation correction increases the LGM magnitude, and enhances the source correction before MIS4. Its effect is clearly dominant for the course of MIS5.5 with a 2-3 times larger impact than the source correction.

EDML $\Delta T_{\text {site }}$ shows a millennial variability quite early along the inception with a first event also at $\sim 119 \mathrm{ky}$ BP and variance ( 2 or 3 more events) until the AIM event at about $110 \mathrm{ky} \mathrm{BP}$, the counterpart of DO 25 (Fig. 8). These events are not due to source temperature changes and remain visible also in $\Delta T_{\text {site, }}$ although their magnitude is quite small compared to the other AIM events observed over the glacial period. The source correction does not remove the supplementary AIM event 2 and does not change much 

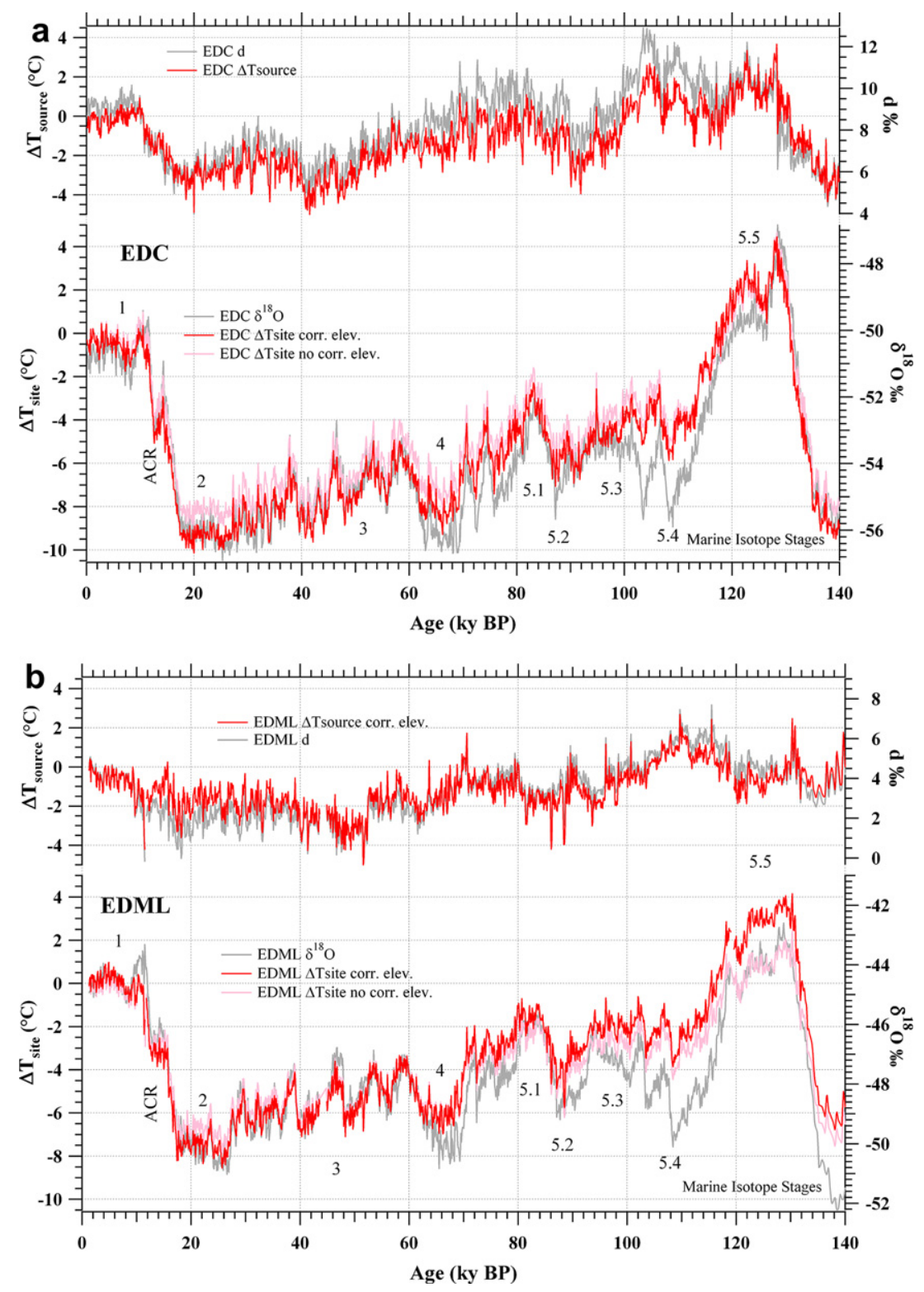

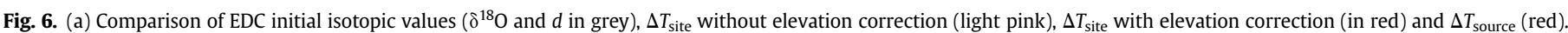

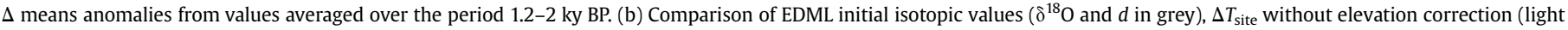
pink), $\Delta T_{\text {site }}$ and $\Delta T_{\text {source }}$ with elevation correction (in red). $\Delta$ means anomalies from values averaged over the period 1.2-2 ky BP.

the shape of $\Delta T_{\text {site }}$ variation along MIS 2 , such as the quite early local glacial maximum at 27- $24 \mathrm{ky} \mathrm{BP.}$

The EDML early Holocene optimum (Fig. 7b), which is strongly attenuated by source correction, is interrupted by a cold event in $T_{\text {site }}$ and also in $T_{\text {source }}$. This drop was already observed in the $d$ record but it was not so clear in the initial $\delta^{18} \mathrm{O}$ data, in particular due to data gaps between 11.57 and 11.76 ky BP. A possible explanation could be that during the early Holocene optimum, a reduced sea-ice extent makes possible the inflow of moisture from high southern latitudes to EDML, formed at low temperature and with low $d$ values. Another cold event is evident in both $\Delta T_{\text {site }}$ and $\Delta T_{\text {source }}$ at about 9.6-9.8 ky BP. These features do not appear in other central Antarctic sites such as Vostok or EDC. This result suggests that there is a potential to characterize local changes in moisture advection specific to regional oceanic basin, using highresolution $d$ measurements. Other rapid events are seen over the Holocene (Fig. 7b) with a magnitude less than $1{ }^{\circ} \mathrm{C}$; although our uncertainty in temperature reconstruction could be larger, this variability is similar to what was observed for the Holocene in other Antarctic sites (Masson et al., 2000; Vimeux et al., 2001).

Both EDML $\Delta T_{\text {source }}$ and $d$ (Fig. $6 \mathrm{~b}$ ) show quite high values at MIS6 which may arise from an inadequate upstream/elevation correction. For termination II, the signal is quite noisy (not enough temporal resolution) but there seems to be also a two-step increase. The signal is quite noisy at the beginning of the early optimum with two spikes of $d / \Delta T_{\text {source }}$ at the beginning of the early MIS5.5. Over the course of MIS5.5, EDML $d$ and $\Delta T_{\text {source }}$ do not show such a large increase above present-day levels as in EDC. The isotopic inversion completely changes the shape of MIS5.5 variations with increasing $d$ versus decreasing $\Delta T_{\text {source. }}$. From 110 to $100 \mathrm{ky} \mathrm{BP} \Delta T_{\text {source }}$ is decreasing at EDML but increasing at EDC. This could be due to different patterns of climate change at regional scale in different sectors of Antarctica.

Fig. 8 reports a 500-year smoothing of EDC (upper panel) and EDML (bottom panel) $\Delta T_{\text {site }}$ and $\Delta T_{\text {source }}$ profiles (all corrected for elevation effect changes), along with $\delta^{18} \mathrm{O}$ and $d$ profiles, in order to 

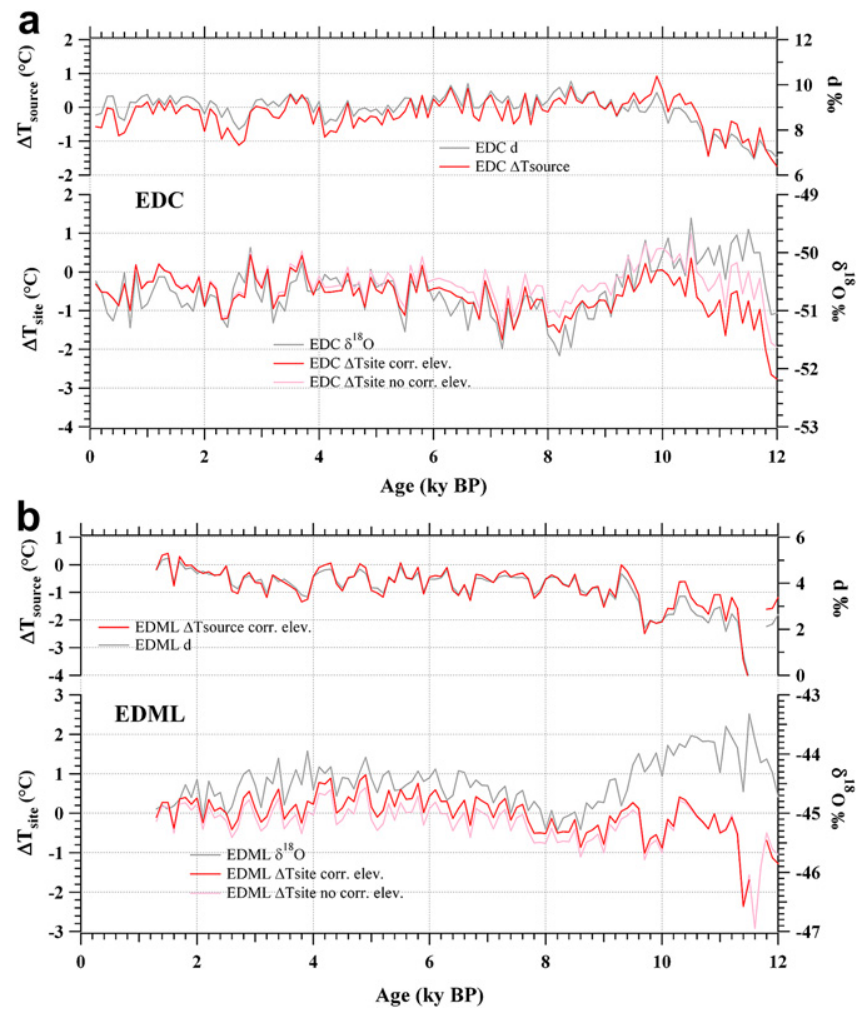

Fig. 7. (a) The same as Fig. 6a but showing a zoom over the Holocene for EDC ice core (b) The same as Fig. 6b but showing a zoom over the Holocene for EDML ice core.

look at the millennial scale climate variability during the last glacial period. The 500-year smoothing has been chosen in order to circumvent the problem of a low signal to noise ratio at higher frequencies. EPICA Community Members (2006) and Jouzel et al.
(2007) have shown a one-to-one coupling, by the bipolar seesaw, between all Antarctic AIM and Greenland Dansgaard-Oeschger events in both drilling sites. Here, we want to evaluate the impact of source corrections and look at the timing between the climate signals recorded in $\delta^{18} \mathrm{O}$ and $d$ records obtained from two ice cores influenced by two different oceanic sectors.

All the AIM events in both EDML and EDC $\Delta T_{\text {site }}$ are clearly visible also after the source correction. There is a robust AIM $\delta^{18} \mathrm{O} /$ $T_{\text {site }}$ shape difference between EDC and EDML, the former being more triangular and the latter more squared. This feature, persistent also after moisture source corrections, points to different climate behaviour within the Atlantic sector compared to the Indian one, with a more instant response of the South Atlantic and/ or the Atlantic sector of the Southern Ocean to rapid changes in the Atlantic Meridional Overturning Circulation initiated in the North Atlantic. The millennial variability of the moisture source temperature at EDML seems noisier compared to the one observed at EDC. The EDC $d$ record also shows all the AIM events and in some cases, such as at the glacial inception, the events are larger and of increasing magnitude than the corresponding $\Delta T_{\text {site }}$ peaks. Generally, during AIM events the $d$ and $\delta^{18} \mathrm{O}$ are in anti-phase: this is particularly evident in the EDC core. When $\delta^{18} \mathrm{O}$ reaches its maximum value, during an AIM event, $d$ starts to increase. The effect of the moisture source correction is, generally, to bring $\Delta T_{\text {site }}$ and $\Delta T_{\text {source }}$ slightly more in phase, so at the end the $\Delta T_{\text {source }}$ is lagging behind the $\Delta T_{\text {site }}$.

In particular, the events 25 and the previous one (marked with question marks in Fig. 8) at about 110 and 115 ky BP, respectively, are more prominent and clearer in $\Delta T_{\text {source }}$ than in $\Delta T_{\text {site. }}$ Capron et al. (2010) reports a very weak synchronization of the DO event 25 and its Antarctic counterpart in the EDML ice core. This event, although present after the moisture source correction, is very weak at EDML and better defined at EDC. The event 24, which in the EDC $\Delta T_{\text {source }}$ is so clearly defined, is practically not discernible in the EDML $\Delta T_{\text {source }}$ profile. Only the events 24 and 23 are damped out a little in the EDC site reconstruction compared to the initial $\delta^{18} \mathrm{O}$ record.
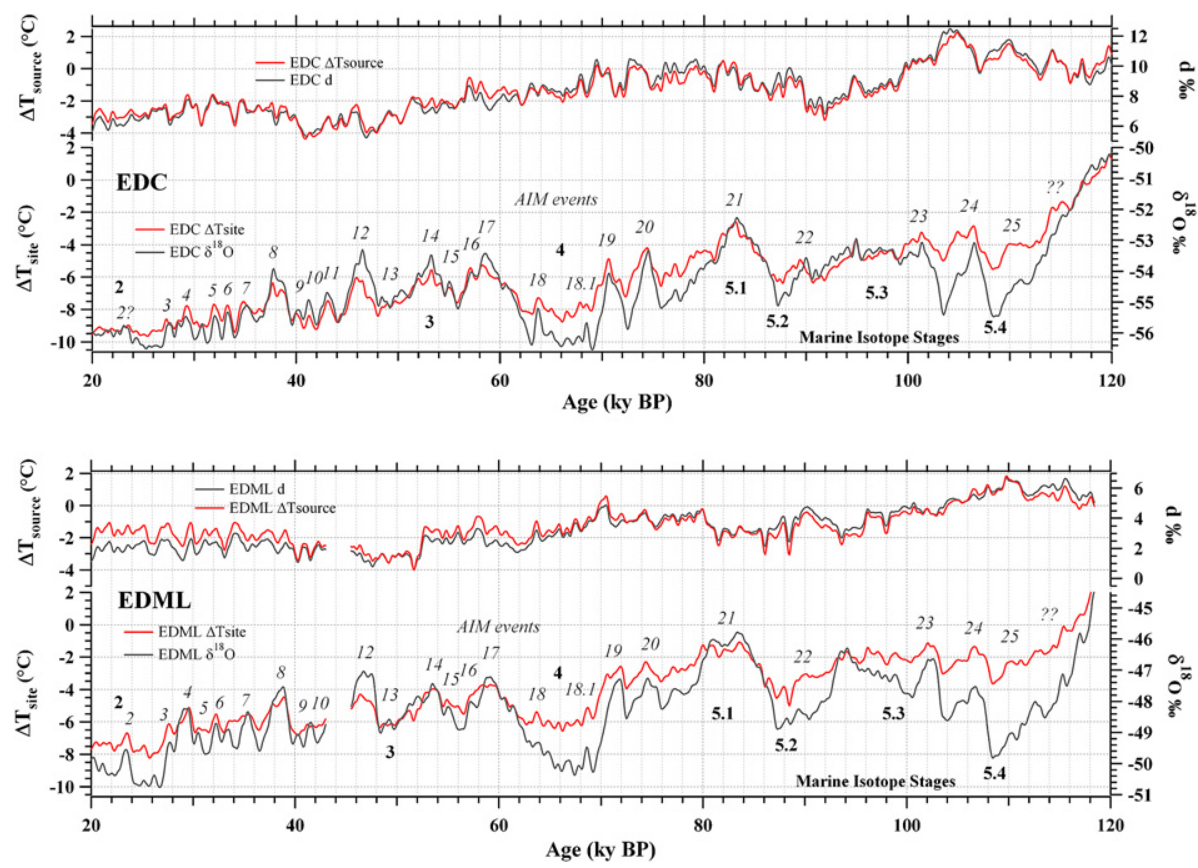

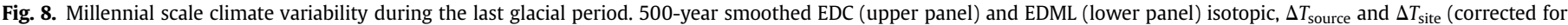

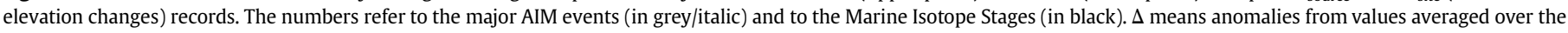
period 1.2-2 ky BP. 
Our inversion based on the MCIM model leads to a slope between $\Delta T_{\text {site }}$ and $\Delta \delta \mathrm{D}_{\text {corr }}$ on average of $6.06 \% /{ }^{\circ} \mathrm{C}$ at Dome $\mathrm{C}$, nearly identical to the classical spatial slope for present-day precipitation of $6.04 \%$ ol ${ }^{\circ} \mathrm{C}$ (Lorius and Merlivat, 1977). For EDML the slope between $\Delta T_{\text {site }}$ and $\Delta \delta^{18} \mathrm{O}_{\text {corr }}$, corrected for elevation changes is $1.00 \% /{ }^{\circ} \mathrm{C}$. This value is fairly similar (within $22 \%$ ) to the classical approach that uses the present-day spatial slope value of $0.82 \% /{ }^{\circ} \mathrm{C}$ determined for the Dronning Maud Land area by Oerter et al. (1999).

The temperature difference simulated by the ECHAM4 model between the LGM and pre-industrial is also close to the one calculated by our approach with a $\Delta T_{\text {model }}$ of $-8.1^{\circ} \mathrm{C}$ and $-8.4{ }^{\circ} \mathrm{C}$ against our $\Delta T_{\text {site }}$ (corrected also for elevation changes) of $-9.3^{\circ} \mathrm{C}$ and of $-7.4{ }^{\circ} \mathrm{C}$ for EDC and EDML, respectively. However, ECHAM4 gives the correct estimates of temperature and $\delta^{18} \mathrm{O}$ changes between the present day and LGM, only because it uses the Peltier (1994) ice sheet topography which at LGM is $400 \mathrm{~m}$ higher than the present day, in contrast to the ice core glaciological model estimates suggesting 100-200 $\mathrm{m}$ lower than at present in central Antarctica (Masson-Delmotte et al., 2006b, 2010).

\section{Temperature gradient and comparison with chemistry records}

A 700-year running average of the reconstructed source-to-site temperature gradient, $\Delta T_{\text {source }}-\Delta T_{\text {site, }}$, is displayed in Fig. 9a (EDC) and $b$ (EDML) along with the non-sea-salt calcium (nssCa) and seasalt sodium ( $\mathrm{ssNa}$ ) flux profiles. The initial isotopic values as well as the $\Delta T_{\text {source }}$ and $\Delta T_{\text {site }}$ profiles are also reported on the same figures. Note that the temperature gradient is strongly correlated with $\Delta T_{\text {site, }}\left(r^{2}=0.9\right)$, indicating that it is the Antarctic temperature, hence, the polar amplification of temperature changes, that controls it. The nssCa flux is a proxy for continental dust input (e.g. Wolff et al., 2006; Fischer et al., 2007). Recent studies have shown that the nssCa (and dust) flux is closely coupled to Antarctic site temperature during cold glacial climates (Fischer et al., 2007; Lambert et al., 2008; Röthlisberger et al., 2008). Linear regressions have been performed on 100-year resampled data for different time periods, namely the Holocene (0-11.5 ky BP), the glacial (20-105 ky BP) and the MIS5.5 (120-130 ky BP), for both EDC and EDML ice cores, in order to check quantitatively the correlation between the different profiles. During the Holocene, no significant correlations have been found, although the lower variability observed during interglacials may impact our ability to find significant correlations. On the contrary, during the glacial period a similar situation has been found at both drilling sites for nssCa, which is well correlated to $\Delta T_{\text {site }}\left(r^{2}=0.65\right.$ for EDML and 0.56 for EDC, respectively) as well as to source-to-site temperature gradient $\left(r^{2}=0.62\right.$ and 0.56$)$ and $\delta^{18} \mathrm{O}\left(r^{2}=0.62\right.$ and 0.68$)$. During MIS5.5 no significant correlations between nssCa flux and temperatures have been observed. Analysis of the differential dust changes between EDML and EDC has shown that the dust variations are not strongly linked to changes in zonal dust transport to Antarctica (Fischer et al., 2007). Thus, this excludes substantially stronger zonal wind speeds in the Southern Ocean (SO) resulting from a higher temperature gradient over the SO, which could be related to our source-site temperature gradient. Only small changes in zonal wind speeds are supported by recent model syntheses (Menviel et al., 2008; Rojas et al., 2008). In contrast, the majority of the dust increase during cold climate periods has been attributed to changes in the Patagonian source strength (Fischer et al., 2007; Lambert et al., 2008). It has been suggested that small to moderate changes in zonal wind speed at the dust source area could significantly change the dust uplift (Röthlisberger et al., 2008). Additionally, higher aridity as well as increased production of glacial outwash (Winckler and Fischer, 2006; Sugden et al., 2009) could have
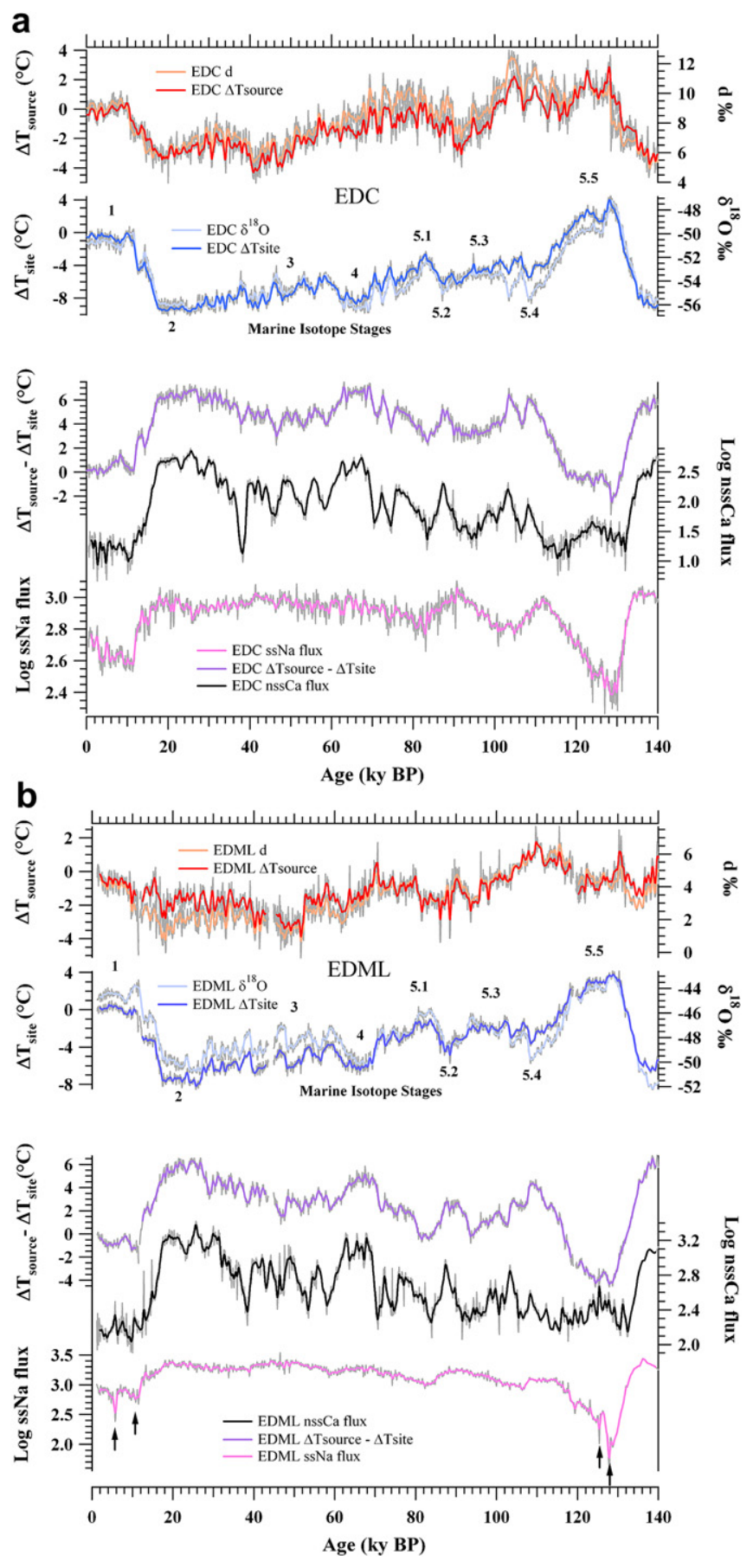

Fig. 9. (a) Source $\left(\Delta T_{\text {source }}\right.$, red), site $\left(\Delta T_{\text {site }}\right.$, blue $)$, and temperature gradient $\left(\Delta T_{\text {source }}{ }^{-}\right.$ $\Delta T_{\text {site, }}$ purple) anomalies compared to the logarithm of sea-salt $\mathrm{Na}$ (pink) and non-seasalt Ca (black) fluxes for the EDC ice core. The $\delta^{18} \mathrm{O}$ (light blue) and $d$ (orange) data are also reported. A 700-year smoothing (bold lines) is performed on 100-year time step data (grey thin lines). $\Delta$ means anomalies from values averaged over the period 1.2-2 ky BP. (b) Source $\left(\Delta T_{\text {source}}\right.$, red), site $\left(\Delta T_{\text {site, }}\right.$ blue), and temperature gradient ( $\Delta T_{\text {source }}-\Delta T_{\text {site, }}$, purple) anomalies compared to the logarithm of ssNa (pink) and nssCa (black) fluxes for the EDML ice core. The $\delta^{18} \mathrm{O}$ (light blue) and $d$ (orange) data are also reported. A 700-year smoothing (bold lines) is performed on 100-year time step data (grey thin lines). $\Delta$ means anomalies from values averaged over the period $1.2-2 \mathrm{ky} \mathrm{BP}$. The small arrows indicate ssNa minima (see text, Section 7).

contributed to the glacial dust increase. The strongest cooling of the ocean surface in the Atlantic sector of the SO during the LGM, most likely related to a significant decline in precipitation rates, is found north of $50^{\circ} \mathrm{S}$ (Gersonde et al., 2005), i.e. at the latitude of the Patagonian dust source region. Accordingly, we conclude that the 
cooling and drying in this region, leading to enhanced dust mobilization, is in phase with the temperature changes in Antarctica, potentially explaining the high correlation of dust and $\Delta T_{\text {site. }}$

On the other hand, the ssNa flux is considered to be a proxy for regional sea-ice extent at EDC and EDML (Wolff et al., 2003; Fischer et al., 2007) and, thus, changes in sea-ice extent may affect the availability of SO moisture sources. However, the sensitivity of ssNa flux as a proxy for sea-ice extent is low during full glacial conditions due to the long atmospheric transport of sea-salt aerosol from the northern sea-ice edge to the interior of the Antarctic ice sheet (Fischer et al., 2007; Röthlisberger et al., 2010). Indeed, during the glacial period the ssNa flux at EDC is related neither to the temperature gradient nor to $\delta^{18} \mathrm{O}$ with only a very weak correlation to $\Delta T_{\text {site }}\left(r^{2}=0.23\right)$. A somewhat different situation is found at EDML where ssNa flux shows a good correlation with $\Delta T_{\text {site }}$ $\left(r^{2}=0.61\right)$ during the glacial and a lower one with both the temperature gradient and $\delta^{18} \mathrm{O}\left(r^{2}=0.40\right.$ for both profiles $)$. The correlation is even higher when also the glacial/interglacial transitions are taken into account, where ssNa as a sea-ice proxy becomes more sensitive. In other words, the ssNa flux seems to be linked more strongly to the reconstructed $\Delta T_{\text {site }}$ at EDML than EDC during the glacial period. Potentially, this results from the sensitivity of ssNa flux at EDML to changes of both the summer and winter sea ice in this SO sector while summer sea ice had not substantially changed in the Indian Ocean sector of the SO (Gersonde et al., 2005). The perennial sea-ice cover over the source region for EDML leads to a pronounced radiative cooling of air masses advected to EDML year-round and, thus, to a strong decline in $\delta^{18} \mathrm{O}$ and $\Delta T_{\text {site, }}$ which could explain the rather high correlation of ssNa and $\Delta T_{\text {site }}$ in this region. Moreover, a weak correlation between $d$ and ssNa flux is found at EDML $\left(r^{2}=0.45\right)$, which is higher than at $\operatorname{EDC}\left(r^{2}=0.29\right)$. If the ssNa flux at EDML is reflecting changes in sea-ice extent, this will have an influence on $d$ values too. Changes in sea-ice extent have a direct influence on stable isotopic ratios by changing the location of the moisture sources (Noone and Simmonds, 2004).

The ssNa flux at EDML during MIS5.5 shows a good relation with $\delta^{18} \mathrm{O}\left(r^{2}=0.73\right)$, a lower one with $\Delta T_{\text {site }}\left(r^{2}=0.53\right)$ and a weaker one with the source-to-site temperature gradient $\left(r^{2}=0.44\right)$. Again significant variations in the sea-ice coverage in this ocean basin during MIS5.5 (Bianchi and Gersonde, 2002) may control the cooling of air reaching EDML and, thus, $\Delta T_{\text {site. }}$ In the EDML chemistry records are two pronounced sea-salt sodium minima (Fig. 9b) coherent with higher non-sea-salt calcium values, which are both located at the interglacial maxima in $\Delta T_{\text {site }}$ both at Holocene and MIS5.5. Smaller correlation values are found at EDC $\left(r^{2}=0.17,0.46\right.$ and 0.29 respectively), suggesting, also for warm periods, a tighter coupling of $\delta^{18} \mathrm{O}$ and $\Delta T_{\text {site }}$ with ssNa flux at EDML compared to EDC. This could be related to different atmospheric circulation and precipitation patterns between the Holocene and MIS5.5 possibly also related to changes in seasonal sea-ice extension, more important at EDML than EDC during the warmer MIS5.5 (Fischer et al., 2007). However, $d$ shows only a very low correlation with ssNa flux at both EDML and EDC $\left(r^{2}=0.18\right.$ and 0.20 , respectively) during MIS5.5.

\section{Conclusions}

In summary, we presented here new $d$ data from the two EPICA drilling sites, one facing the Atlantic Ocean, EDML, and the other facing the Indian Ocean, EDC.

The EDML and $\operatorname{EDC} \delta^{18} \mathrm{O}$ records show the main climate features well known for central East Antarctica as well as similar millennial scale climate variability during the last glacial period. The lower present-day $d$ value found at EDML, compared to Dome $\mathrm{C}$, is reflecting a more southward moisture origin for EDML, in agreement with what is suggested by backward-trajectory analyses (Reijmer et al., 2002) and isotopic modelling, placing the moisture sources for EDML in the Atlantic Ocean and for EDC at the midlatitudes of the Indian Ocean (Delaygue et al., 2000).

However, a long-term difference is observed between the two sites, with the largest $\delta^{18} \mathrm{O}$ and $d$ differences observed during MIS5.5 and the glacial inception, persisting also after past $\delta^{18} \mathrm{O}$ seawater changes and elevation corrections. We suggest that a possible source of error could be the estimation of accumulation rate from the isotopic data, which are used as input in the glaciological models controlling altitude changes of the drill sites. However, regional climate anomalies, like differences in precipitation regimes or sea-ice extent, during MIS5.5 between the two sites, could also be consistent with the observed EDML-EDC $\delta^{18} \mathrm{O}$ and $d$ gradient anomalies.

The temporal temperature/isotope slope obtained from the ECHAM4 simulations for the EDML model grid region is in fair agreement with its modern spatial analogue, as also is the case for the EDC area (Jouzel et al., 2007), supporting the MCIM based approach used in this study.

Although we are aware of the limitations (i.e. no mixing of different moisture sources) and uncertainties related to our temperature reconstruction method, high-resolution records of $\Delta T_{\text {site }}$ and $\Delta T_{\text {source }}$ have been extracted from both EPICA ice cores, using a modelling approach. The results presented in this study show a limited influence of $d$ on Antarctic temperature reconstructions both at EDML and EDC with only a higher impact at glacial inceptions. During the entire glacial period, AIM events in both EDML and EDC $\Delta T_{\text {site }}$ are clearly visible also after the source correction, suggesting that these are real climate features. At the glacial inception, the EDC $d$ and $\Delta T_{\text {source }}$ records show events of increasing magnitude with time and larger than the corresponding $\Delta T_{\text {site }}$ ones. Generally, when $\delta^{18} \mathrm{O}$ reaches its maximum value, during an AIM event, $d$ starts to increase. The increase of $d$ could be linked to SST changes or a shift of the moisture sources, but so far this parameter is not conclusive in distinguishing between these two mechanisms. However, the negative correlation of $d$ signal with SAM (Schmidt et al., 2007), would suggest that higher (lower) $d$ values could be related to a northward (southward) displacement of moisture sources associated to a reduction (intensification) of westerlies.

The comparison of the temperature reconstructions (both $\Delta T_{\text {site }}$ and $\left.\Delta T_{\text {source }}\right)$ and of the source-to-site temperature gradient with the aerosol fluxes (nssCa and ssNa) have shown that: (i) there is a strong coupling of the dust fluxes (nssCa) with Antarctic temperatures during cold climate states, as previously suggested also by other authors (Wolff et al., 2006; Fischer et al., 2007; Lambert et al., 2008; Röthlisberger et al., 2008); (ii) the ssNa flux seems more closely related to the reconstructed $\Delta T_{\text {site }}$ at EDML than EDC during the glacial period. To a lesser extent, this is also the case during MIS5.5, in contrast to the absence of a significant correlation during the Holocene. Schlosser et al. (2008a) suggested that the influence of cyclonic activity on precipitation may affect also the interior parts of the continent and not only the coastal areas for the present-day precipitation regime of Dronning Maud Land. They also suggest that changes in sea-ice extent, influencing cyclogenesis and storm tracks may affect the precipitation regime of the area. Interestingly, the investigation of the decadal variability in highresolution aerosol chemistry records from the EPICA ice cores suggests a stronger cyclonic influence during warm periods than during glacial intervals (Bigler et al., 2010). A different displacement of sea ice in the Atlantic versus Indian Ocean would have a direct effect on the isotopic composition of precipitation and the ssNa flux, influencing in a differential way the two drilling sites during 
the warmer MIS5.5 period. This is pointing to a possible climate variability at regional scale affecting in a different way the two oceanic sectors of the Southern Ocean, the Atlantic and Indian Ocean. This is not limited to MIS5.5 but could also explain the different shape of the millennial scale climate variability (AIM events) between EDC and EDML observed during the last glacial period, and different trends during the Holocene.

As already noted above, some simplifications have been done. Among them is the fact that in reality the air masses can be replenished with a combination of different moisture sources and also that the effect of relative humidity changes has been neglected when considering the past climate conditions at moisture sources only in terms of $T_{\text {source }}$. Recently, Landais et al. (2008) suggested that the increase of ${ }^{17} \mathrm{O}_{\text {excess }}$ in the Vostok ice core going from the past glacial to the present interglacial is related to higher relative humidity and/or wind speeds over the source oceanic regions during the glacial period. A future perspective could be to combine $d$ and measurements of ${ }^{17} \mathrm{O}_{\text {excess }}$ in the EPICA ice cores. This is expected to differentiate between the SST and relative humidity effects on $d$.

\section{Acknowledgements}

This work is a contribution to the European Project for Ice Coring in Antarctica (EPICA), a joint European Science Foundation/European Commission scientific programme, funded by the EU (EPICAMIS) and by national contributions from Belgium, Denmark, France, Germany, Italy, the Netherlands, Norway, Sweden, Switzerland and the United Kingdom. The main logistic support was provided by IPEV and PNRA (at Dome C) and AWI (at Dronning Maud Land). LSCE work is funded by ANR. This is EPICA publication no 235.

\section{References}

Barrows, T.T., Juggins, S., De Deckker, P., Calvo, E., Pelejero, C., 2007. Long-term sea surface temperature and climate change in the Australian-New Zealand region. Paleoceanography 22, PA2215. doi:10.1029/2006PA001328.

Bianchi, C., Gersonde, R., 2002. The Southern Ocean surface between Marine Isotope Stage 6 and 5d: Shape and timing of climate changes. Palaeogeogr. Palaeoclimatol. Palaeoecol 187, 151-177.

Bigler, M., Röthlisberger, R., Lambert, F., Stocker, T.F., Fischer, H., Wolff, E.W., Castellano, E., Udisti, R., 2010. Atmospheric decadal variability from highresolution Dome $\mathrm{C}$ ice core records of aerosol constituents beyond the last interglacial. Quat. Sci. Rev. 29, 324-337.

Bintanja, R., van de Wal, R.S.W., Oerlemans, J., 2005. Modelled atmospheric temperatures and global sea levels over the past million years. Nature 437, 125-128.

Capron, E., Landais, A., Lemieux-Dudon, B., Schilt, A., Masson-Delmotte, V., Buiron, D., Chappellaz, J., Dahl-Jensen, D., Johnsen, S., Leuenberger, M., Loulergue, L., Oerter, H., 2010. Synchronising EDML and NorthGRIP ice cores using $\delta^{18} \mathrm{O}$ of atmospheric oxygen $\delta^{18} \mathrm{O}_{\text {atm }}$ and $\mathrm{CH}_{4}$ measurements over MIS 5 (80-123 ka). Quat. Sci. Rev. 29, 222-234.

Ciais, P., Jouzel, J., 1994. Deuterium and oxygen 18 in precipitation: isotopic model, including mixed cloud processes. J. Geophys. Res. 99, 16793-16803.

Dansgaard, W., 1964. Stable isotopes in precipitation. Tellus 16, 436-468.

Delaygue, G., Masson, V., Jouzel, J., Koster, R.D., Healy, R.J., 2000. The origin of Antarctic precipitation: a modelling approach. Tellus 52B, 19-36.

Dreyfus, G.B., Jouzel, J., Bender, M.L., Landais, A., Masson-Delmotte, V., Leuenberger, M., 2010. Firn processes and $\delta^{15} \mathrm{~N}$ : potential for a gas-phase climate proxy. Quat. Sci. Rev. 29, 28-42.

EPICA community members, 2004. Eight glacial cycles from an Antarctic ice core. Nature 429, 623-628.

EPICA community members, 2006. One-to-one coupling of glacial climate variability in Greenland and Antarctica. Nature 444, 195-198.

Fisher, D.A., 1990. A zonally averaged stable-isotope model coupled to a regional variable elevation stable isotope model. Ann. Glaciol 14, 65-72.

Fischer, H., Fundel, F., Ruth, U., Twarloh, B., Wegner, A., Udisti, R., Becagli, S., Castellano, E., Morganti, A., Severi, M., Wolff, E., Littot, G., Röthlisberger, R., Mulvaney, R., Hutterli, M.A., Kaufmann, P., Federer, U., Lambert, F., Bigler, M., Hansson, M., Jonsell, U., de Angelis, M., Boutron, C., Siggaard-Andersen, M.-L., Steffensen, J.P., Barbante, C., Gaspari, V., Gabrielli, P., Wagenbach, D., 2007. Reconstruction of millennial changes in dust emission, transport and regional sea ice coverage using the deep EPICA ice cores from the Atlantic and Indian Ocean sector of Antarctica. Earth. Planet. Sci. Lett. 260, 340-354.
Gersonde, R., Crosta, X., Abelmann, A., Armand, L., 2005. Sea-surface temperature and sea ice distribution of the Southern Ocean at the EPILOG Last Glacial Maximum-a circum-Antarctic view based on siliceous microfossil records. Quat. Sci. Rev. 24, 869-896.

Govin, A., Michel, E., Labeyrie, L., Waelbroeck, C., Dewilde, F., Jansen, E., 2009 Evidence for northward expansion of Antarctic Botton Water mass in the Southern Ocean during the last glacial inception. Paleoceanography 24, PA1202. doi:10.1029/2008PA001603.

Graf, W., Oerter, H., Reinwarth, O., Stichler, W., Wilhelms, F., Miller, H., Mulvaney, R., 2002 Stable-isotope records from Dronning Maud Land, Antarctica. Ann. Glaciol 35, 195-201.

Helsen, M.M., van de Wal, R.S.W., van den Broeke, M.R., Masson-Delmotte, V. Meijer, H.A.J., Scheele, M.P., Werner, M., 2006. Modeling the isotopic composition of Antarctic snow using backward trajectories: simulation of snow pit records. J. Geophys. Res. 111, D15109. doi:10.1029/2005JD006524.

Helsen, M.M., van de Wal, R.S.W., van den Broeke, M.R., 2007. The isotopic composition of present-day Antarctic snow in a Lagrangian atmospheric simulation. J. Clim 20, 739-756.

Hoffmann, G., Werner, M., Heimann, M., 1998. Water isotope module of the ECHAM atmospheric general circulation model: a study on time scales from days to several years. J. Geophys. Res. 103 (D14), 16,871-16,896.

Hoffmann, G., Jouzel, J., Masson, V., 2000. Stable water isotopes in atmospheric general circulation models. Hydrol. Processes 14, 1385-1406.

Huybrechts, P., Rybak, O., Pattyn, F., Ruth, U., Steinhage, D., 2007. Ice thinning upstream advection, and non-climatic biases for the upper 89\% of the EDML ice core from a nested model of the Antarctic ice sheet. Clim. Past 3, 577-589.

IPCC, 2007. Climate Change 2007-The Physical Science Basis. Cambridge University Press, Cambridge.

Johnsen, S.J., Dansgaard, W., White, J.W.C., 1989. The origin of Arctic precipitation under present and glacial conditions. Tellus 41B, 452-469.

Joussaume, S., Taylor, K.E., 1995. Status of the Paleoclimate Modeling Intercomparison Project (PMIP). Proceedings of the first international AMIP scientific conference, WCRP 92, 425-430.

Jouzel, J., Merlivat, L., 1984. Deuterium and oxygen 18 in precipitation: modeling of the isotopic effects during snow formation. J. Geophys. Res. 89, 11749-11757.

Jouzel, J., Merlivat, L., Lorius, C., 1982. Deuterium excess in an East Antarctic ice core suggests higher relative humidity at the oceanic surface during the last glacial maximum. Nature 299, 688-691.

Jouzel, J., Vimeux, F., Caillon, N., Delaygue, G., Hoffmann, G., Masson-Delmotte, V., Parrenin, F., 2003. Magnitude of isotope/temperature scaling for interpretation of central Antarctic ice cores. J. Geophys. Res. 108 (D12), 4361. doi: 10.1029/ 2002JD002677.

Jouzel, J., Masson-Delmotte, V., Cattani, O., Dreyfus, G., Falourd, S., Hoffmann, G. Minster, B., Nouet, J., Barnola, J.M., Chappellaz, J., Fischer, H., Gallet, J.C., Johnsen, S., Leuenberger, M., Loulergue, L., Luethi, D., Oerter, H., Parrenin, F., Raisbeck, G., Raynaud, D., Schilt, A., Schwander, J., Selmo, E., Souchez, R. Spahni, R., Stauffer, B., Steffensen, J.P., Stenni, B., Stocker, T.F., Tison, J.L., Werner, M., Wolff, E.W., 2007. Orbital and millennial Antarctic climate variability over the past 800,000 years. Science $317,793-796$.

Kavanaugh, J.L., Cuffey, K.M., 2003. Space and time variation of $\delta^{18} \mathrm{O}$ and $\delta \mathrm{D}$ in Antarctic precipitation revisited. Global Biogeochem. Cycles 17, 1017, doi:10.1029/2002GB001910.

Lambert, F., Delmonte, B., Petit, J.R., Bigler, M., Kaufman, P.R., Hutterli, M.A. Stocker, T.F., Ruth, U., Steffensen, J.P., Maggi, V., 2008. Dust-climate couplings over the past 800,000 years from the EPICA Dome C ice core. Nature 452, 616-619.

Landais, A., Barnola, J.M., Kawamura, K., Caillon, N., Delmotte, M., Van Ommen, T. Dreyfus, G., Jouzel, J., Masson-Delmotte, V., Minster, B., Freitag, J., Leuenberger, M., Schwander, J., Huber, C., Etheridge, D., Morgan, V., 2006. Firnair $\delta^{15} \mathrm{~N}$ in modern polar sites and glacial-interglacial ice: a model-data mismatch during glacial periods in Antarctica? Quat. Sci. Rev. 25, 49-62.

Landais, A., Barkan, E., Luz, B., 2008. Record of $\delta^{18} \mathrm{O}$ and ${ }^{17} \mathrm{O}$-excess in ice from Vostok Antarctica during the last 150,000 years. Geophys. Res. Lett. 35, L02709. doi:10.1029/2007GL032096.

Lisiecki, L.E., Raymo, M.E., 2005. A Pliocene-Pleistocene stack of 57 globally distributed benthic $\delta^{18} \mathrm{O}$ records. Paleoceanography 20. doi:10.1029/ 2004 PA001071.

Lorius, C., Merlivat, L., 1977. Distribution of mean surface stable isotope values in East Antarctica: Observed changes with depth in a coastal area. In: Isotopes and Impurities in Snow and Ice. IAHS Publ. 118, pp. 127-137.

Loulergue, L., Schilt, A., Spahni, R., Masson-Delmotte, V., Blunier, T., Lemieux, B. Barnola, J.-M., Raynaud, D., Stocker, T.F., Chappelaz, J., 2008. Orbital and millennial-scale features of atmospheric $\mathrm{CH}_{4}$ over the past 800,000 years. Nature 453, 383-386.

Lüthi, D., Le Floch, M., Bereiter, B., Blunier, T., Barnola, J.-M., Siegenthaler, U., Raynaud, D., Jouzel, J., Fischer, H., Kawamura, K., Stocker, T.F., 2008. High resolution carbon dioxide concentration record $650,000-800,000$ years before present. Nature 453, 379-382.

Masson, V., Vimeux, F., Jouzel, J., Morgan, V., Delmotte, M., Ciais, P., Hammer, C., Johnsen, S., Lipenkov, V.Y., Mosley-Thompson, E., Petit, J.-R., Steig, E.J., Stievenard, M., Vaikmae, R., 2000. Holocene climate variability in Antarctica based on 11 ice-core isotopic records. Quat. Res. 54, 348-358.

Masson-Delmotte, V., Stenni, B., Jouzel, J., 2004. Common millennial-scale variability of Antarctic and Southern Ocean temperatures during the past 5000 years reconstructed from the EPICA Dome C ice core. The Holocene 14 (2), 145-151.

Masson-Delmotte, V., Jouzel, J., Landais, A., Stievenard, M., Johnsen, S.J., White, J.W.C., Sveinbjornsdottir, A., Fuhrer, K., 2005. Deuterium excess reveals 
millennial and orbital scale fluctuations of Greenland moisture origin. Science 309, 118-121.

Masson-Delmotte, V., Dreyfus, G., Braconnot, P., Johnsen, S., Jouzel, J., Kageyama, M. Landais, A., Loutre, M.F., Nouet, J., Parrenin, F., Raynaud, D., Stenni, B., Tuenter, E. 2006a. Past temperature reconstructions from deep ice cores: relevance for future climate change. Clim. Past 2, 145-165.

Masson-Delmotte, V., Kageyama, M., Braconnot, P., Charbit, S., Krinner, G., Ritz, C., Guilyardi, E., Jouzel, J., Abe-Ouchi, A., Crucifix, M., Gladstone, R.M., Hewitt, C.D. Kitoh, A., Legrande, A., Marti, O., Merkel, U., Motoi, T., Ohgaito, R., Otto-Bliesner, B. Peltier, R.W., Ross, I., Valdes, P., Vettoretti, G., Weber, S.L., Wolk, F., 2006b. Past and future polar amplification of climate change: climate model intercomparisons and ice-core constraints. Clim. Dyn.. doi:10.1007/s00382-005-0081-9.

Masson-Delmotte, V., Hou, S., Ekaykin, A., Jouzel, J., Aristarain, A., Bernardo, R.T., Bromwich, D., Cattani, O., Delmotte, M., Falourd, S., Frezzotti, M., Gallée, H. Genoni, L., Isaksson, E., Landais, A., Helsen, M.M., Hoffmann, G., Lopez, J., Morgan, V., Motoyama, H., Noone, D., Oerter, H., Petit, J.R., Royer, A., Uemura, R. Schmidt, G.A., Schlosser, E., Simões, J.C., Steig, E., Stenni, B., Stievenard, M., van den Broeke, M.R., van de Wal, R.S.W., van de Berg, W.J., Vimeux, F., White, J.W.C., 2008. A review of Antarctic surface snow isotopic composition: observations, atmospheric circulation and isotopic modeling. J. Climate 21, 3359-3387.

Masson-Delmotte, V., Stenni, B., Pol, K., Braconnot, P., Cattani, O., Falourd, S., Kageyama, M., Jouzel, J., Landais, A., Minster, B., Krinner, G., Johnsen, S., Röthlisberger, R., Chappellaz, J., Hansen, J., Mikolajewicz, U., Otto-Bliesner, B., 2010. EPICA Dome $C$ record of glacial and interglacial intensities. Quat. Sci. Rev. 29, 113-128.

Menviel, L., Timmermann, A., Mouchet, A., Timm, O., 2008. Climate and marine carbon cycle response to changes in the strength of the southern hemispheric westerlies. Paleoceanography 23, PA4201.

Merlivat, L., Jouzel, J., 1979. Global climatic interpretation of the deuterium-oxygen 18 relationship for precipitation. J. Geophys. Res. 84, 5029-5033.

Meyer, H., Schönicke, L., Wand, U., Hubberten, H.-W., Friedrichsen, H., 2000. Isotope studies of hydrogen and oxygen in ground ice-Experiences with the equilibration technique. Isot. Environ. Health Stud 36, 133-149.

Noone, D., 2008. The influence of midlatitude and tropical overturning circulation on the isotopic composition of atmospheric water vapour and Antarctic precipitation. J. Geophys. Res. 113. doi:10.1029/2007JD008892.

Noone, D., Simmonds, I., 2004. Sea ice control of water isotope transport to Antarctica and implications for ice core interpretation. J. Geophys. Res. 109, D07105. doi:10.1029/2003JD004228.

North Greenland Ice Core Project Members, 2004. High resolution climate record of the northern hemisphere reaching into the last interglacial period. Nature 431,147-151.

Oerter, H., Graf, W., Wilhelms, F., Minikin, A., Miller, H., 1999. Accumulation studies on Amundsenisen, Dronning Maud Land, Antarctica, by means of tritium, dielectric profiling and stable isotope measurements: first results from the 1995-96 and 1996-97 field seasons. Ann. Glaciol 29, 1-9.

Parrenin, F., Barnola, J.-M., Beer, J., Blunier, T., Castellano, E., Chappellaz, J., Dreyfus, G., Fischer, H., Fujita, S., Jouzel, J., Kawamura, K., Lemieux-Dudon, B. Loulergue, L., Masson-Delmotte, V., Narcisi, B., Petit, J.-R., Raisbeck, G., Raynaud, D., Ruth, U., Schwander, J., Severi, M., Spahni, R., Steffensen, J.P., Svensson, A.M., Udisti, R., Waelbroeck, C., Wolff, E., 2007. The EDC3 chronology for the EPICA Dome C ice core. Clim. Past 3, 485-497.

Peltier, W.R., 1994. Ice age paleotopography. Science 265, 195-201.

Petit, J.R., Jouzel, J., Raynaud, D., Barkov, N.I., Barnola, J.-M., Basile, I., Bender, M. Chappellaz, J., Davis, M., Delaygue, G., Delmotte, M., Kotlyakov, V.M Legrand, M., Lipenkov, V.Y., Lorius, C., Pepin, L., Ritz, C., Saltzman, E. Stievenard, M., 1999. Climate and atmospheric history of the past 420,000 years from the Vostok ice core, Antarctica. Nature 399 (6735), 429-436.

Reijmer, C.H., van den Broeke, M.R., 2001. Moisture sources of precipitation in Western Dronning Maud Land, Antarctica. Antarct. Sci. 13, 210-220.

Reijmer, C.H., van den Broeke, M.R., 2003. Temporal and spatial variability of the surface mass balance in Dronning Maud Land, Antarctica, as derived from automatic weather stations. J. Glaciol 49 (167), 512-520.

Reijmer, C.H., van den Broeke, M.R., Scheele, M.P., 2002. Air parcel trajectories and snowfall related to five deep drilling locations in Antarctica based on the ERA15 dataset. J. Clim 15, 1957-1968.

Roeckner, E., Arpe, K., Bentsson, L., Christoph, M., Claussen, M., Dümenil, L., Esch, M. Giorgetta, M., Schlese, U., Schulzweida, U., 1996. The atmospheric genera circulation model ECHAM-4: Model description and simulation of present day climate. Max-Planck Institut für Meteorologie, Report No. 218, 90 pp.

Rojas, M., Moreno, P., Kageyama, M., Crucifix, M., Hewitt, C., Abe-Ouchi, A., Ohgaito, R., Brady, E.C., Hope, P., 2008. The Southern Westerlies during the last glacial maximum in PMIP2 simulations. Clim. Dyn.. doi:10.1007/s00382-00008-00421-00387.

Röthlisberger, R., Mudelsee, M., Bigler, M., de Angelis, M., Fischer, H., Hansson, M., Lambert, F., Masson-Delmotte, V., Sime, L., Udisti, R., Wolff, E.W., 2008. The Southern Hemisphere at glacial terminations: insights from the Dome $\mathrm{C}$ ice core. Clim. Past 4, 345-356.
Röthlisberger, R., Crosta, X., Abram, N.J., Armand, L., Wolff, E.W., 2010. Potential and limitations of marine and ice core sea ice proxies: An example from the Indian Ocean sector. Quat. Sci. Rev. 29, 296-302.

Ruth, U., Barnola, J.-M., Beer, J., Bigler, M., Blunier, T., Castellano, E., Fischer, H., Fundel, F., Huybrechts, P., Kaufmann, P. Kipfstuhl, S., Lambrecht, A, Morganti, A., Oerter, H., Parrenin, F., Rybak, O., Severi, M., Udisti, R., Wilhelms, F. Wolff, E., 2007. "EDML1": a chronology for the EPICA deep ice core from Dronning Maud Land, Antarctica, over the last 150000 years. Clim. Past 3, 475-484.

Schlosser, E., Duda, M.G., Powers, J.G., Manning, K.W., 2008a. Precipitation regime of Dronning Maud Land, Antarctica, derived from Antarctic Mesoscale Prediction System (AMPS) archive data. J. Geophys. Res. 113, D24108. doi:10.1029/ 2008JD009968.

Schlosser, E., Oerter, H., Masson-Delmotte, V., Reijmer, C., 2008b. Atmospheric influence on the deuterium excess signal in polar firn: implications for ice-core interpretation. J. Glaciol 54 (184), 117-124.

Schmidt, G.A., LeGrande, A.N., Hoffmann, G., 2007. Water isotope expressions of intrinsic and forced variability in a coupled ocean-atmosphere model. J. Geophys. Res. 112, D10103. doi:10.1029/2006JD007781.

Stenni, B., Masson-Delmotte, V., Johnsen, S., Jouzel, J., Longinelli, A., Monnin, E., Röthlisberger, R., Selmo, E., 2001. An oceanic cold reversal during the last deglaciation. Science 293, 2074-2077.

Stenni, B., Jouzel, J., Masson-Delmotte, V., Röthlisberger, R., Castellano, E., Cattani, O. Falourd, S., Johnsen, S.J., Longinelli, A., Sachs, J.P., Selmo, E., Souchez, R., Steffensen, J.P., Udisti, R., 2003. A late-glacial high resolution site and source temperature record derived from the EPICA Dome C isotope records (East Antarctica). Earth Planet. Sci. Lett. 217 (1-2), 183-195.

Sugden, D.E., McCulloch, R.D., Bory, A.J.-M., Hein, A.S., 2009. Influence of Patagonian glaciers on Antarctic dust deposition during the last glacial period. Nature Geoscience 2, 281-285.

Uemura, R., Yoshida, N., Kurita, N., Nakawo, M., Watanabe, O., 2004. An observationbased method for reconstructing ocean surface changes using a 340,000-year deuterium excess record from the Dome Fuji ice core, Antarctica. Geophys. Res. Lett. 31, L13216. doi:10.1029/2004GL019954.

Uemura, R., Matsui, Y., Yoshimura, K., Motoyama, H., Yoshida, N., 2008. Evidence of deuterium excess in water vapor as an indicator of ocean surface conditions. J. Geophys. Res. 113, D19114. doi:10.1029/2008JD010209.

Vimeux, F., Masson, V., Jouzel, J., Stievenard, M., Petit, J.R., 1999. Glacial-interglacial changes in ocean surface conditions in the Southern Hemisphere. Nature 398, 410-413.

Vimeux, F., Masson, V., Jouzel, J., Petit, J.R., Steig, E.J., Stievenard, M., Vaikmae, R. White, J.W.C., 2001. Holocene hydrological cycle changes in the southern hemisphere documented in East Antarctic deuterium excess records. Clim. Dyn. 17, 503-513.

Vimeux, F., Cuffey, K.M., Jouzel, J., 2002. New insights into Southern Hemisphere temperature changes from Vostok ice cores using deuterium excess correction. Earth Planet. Sci. Lett. 203, 829-843.

Vittuari, L., Vincent, C., Frezzotti, M., Mancini, F., Gandolfi, S., Bitelli, G., Capra, A., 2004. Space geodesy as a tool for measuring ice surface velocity in the Dome $C$ region and along the ITASE traverse. Ann. Glaciol 39, 402-408.

Watanabe, O., Jouzel, J., Johnsen, S., Parrenin, F., Shoji, H., Yoshida, N., 2003. Homogeneous climate variability across East Antarctica over the past three glacial cycles. Nature 422, 509-512.

Werner, M., Mikolajewicz, U., Heimann, M., Hoffmann, G., 2000. Borehole versus isotope temperatures on Greenland: Seasonality does matter. Geophys. Res. Lett. 27 (5), 723-726.

Werner, M., Heinmann, M., Hoffmann, G., 2001. Isotopic composition and origin of polar precipitation in present and glacial climate simulations. Tellus 53B, 53-71.

Werner, M., Heimann, M., 2002. Modeling interannual variability of water isotopes in Greenland and Antarctica. J. Geophys. Res. 107, 4001,. doi:10.1029/ 2001JD900253.

Wesche, C., Eisen, O., Oerter, H., Schulte, D., Steinhage, D., 2007. Surface topography and ice flow in the vicinity of the EDML deep drilling site. J. Glaciol 53 (182), $442-448$.

Winckler, G., Fischer, H., 2006. 30,000 years of cosmic dust in Antarctic ice. Science 313, 491.

Wolff, E.W., Rankin, A.M., Röthlisberger, R., 2003. An ice core indicator of Antarctic sea ice production? Geophys. Res. Lett. 30, 2158,. doi:2110.1029/2003GL018454, 2003.

Wolff, E.W., Fischer, H., Fundel, F., Ruth, U., Twarloh, B., Littot, G., Mulvaney, R., Röthlisberger, R., De Angelis, M., Boutron, C., Hansson, M., Jonsell, U., Hutterli, M., Lambert, F., Kaufmann, P., Stauffer, B., Stocker, T.F., Steffensen, J.P., Bigler, M., Siggaard-Andersen, M.-L., Udisti, R., Becagli, S., Castellano, E., Severi, M., Wagenbach, D., Barbante, C., Gabrielli, P., Gaspari, V., 2006. Southern Ocean sea-ice extent, productivity and iron flux over the past eight glacial cycles. Nature 440, 491-496. 